\title{
Architecture in Central India under the Kacchapaghāta Rulers
}

\author{
MICHAEL D. WILLIS
}

\section{Introduction}

Numerous temples are preserved in the territory between the Gangetic plain and the Narmada river. In ancient times, this vast area (conforming approximately to Madhya Pradesh) consisted of several regions with differing cultural and architectural traditions. The northwest portion, round the hill-fort of Gwalior, was known as Gopakșetra from at least the 11 th century (Sinha, 1980; Willis, 1988). It was in this region that the Kacchapaghāta dynasty flourished as the great dominion of the Gurjara Pratihāras was parcelled into a number of independent kingdoms. The most powerful neighbours of the Kacchapaghātas were the Candellas (to the east in ancient Jejākadeśa), the Paramāras (to the south in ancient Mālava) and the Cähamānas (to the west in ancient Virăta and other parts of Rājasthān). While the Pratīhāras struggled to retain Kannauj and the Gangetic plain, these and other dynasties vied for political supremacy. In the competitive environment that prevailed, architecture enjoyed an extraordinary efflorescence and temples of unprecedented scale and complexity were constructed.

The architectural achievements of the Candellas are well known, no doubt because their buildings are in an excellent state of preservation (see Deva, 1959 , 1987). By comparison, the temples of the Kacchapaghātas have been ignored. Setting aside the desultory treatment in survey books (for example, Brown, 1944 [?]; Rowland, 1956, p. 169), the only examination of later temple architecture in the Gwalior region has been provided by Deva (1963$64,1969)$. Of necessity, these contributions provide a first introduction to the subject. Our purpose here, therefore, is to build on Krishna Deva's foundation. This will be done through a discussion of the betterknown monuments as well as several temples which are published here for the first time.

A few preliminary comments are necessary regarding Sanskrit terms and place names. Technical terms in Sanskrit are transcribed according to the currently accepted system. Modern names of temples and locations are not Sanskritized and some attempt has been made to account for current pronunciation in Hindi. Where possible, place names are spelt according to the maps published by the Survey of India and documented in Corpus Topographicum Indiae Antiquae (Part I, Epigraphical Find Spots) by R. Stroobandt (Gent, 1974).

\section{Kacchapaghāta Dynasty}

The Kacchapaghāta dynasty came to prominence in the 10th century after they were able to capture the fortress of Gwalior from the Gurjara Pratihāras. The Sās Bahũ temple inscription, a record which will be mentioned frequently in the following pages, recounts that Vajradāman (c. A.D. 975-1000) "put down the rising power of the ruler of Gâdhinagara [Kannauj] and his proclamation drum...resounded on the fort of Gopādri" (Trivedi, 1979-91, p. 542, v. 6). The Kacchapaghātas subsequently ruled from the twin centres of Sihoniyā (ancient Simhapānīya) and Gwalior (ancient Gopādri, Gopagiri); collateral branches of the family had their seats at Dubkund (ancient Dobha) and Narwar (ancient Nalapura). We can show the sequence and distribution of the known Kacchapaghāta princes as follows (based on Dvivedi 1980 with slight modifications): 


\section{Kacchapaghāta Dynasty}

\begin{tabular}{|c|c|c|c|c|c|}
\hline \multicolumn{2}{|c|}{ Simhapāniya/Gopādri } & \multicolumn{2}{|l|}{ Dobha } & \multicolumn{2}{|l|}{ Nalapura } \\
\hline Lakșmana & (c. $950-75$ ) & & & & \\
\hline Vajradäman & (c. $975-1000$ ) & & & & \\
\hline Mangalarāja & (c. $1000-1015)$ & Yuvarāja & (c. 1000) & & \\
\hline Kïtirāja & (c. $1015-35)$ & Arjuna & (c. $1015-35)$ & & \\
\hline Mūladeva & (c. $1035-55$ ) & Abhimanyu & (c. $1035-45$ ) & & \\
\hline Devapāla & (c. $1055-85$ ) & Vijayapāla & (c. 1045-70) & & \\
\hline Padmapāla & (c. $1085-90$ ) & Vikramasimha & (c. $1075-1100$ ) & Gaganasimha & (c. $1075-90)$ \\
\hline Mahīpa̋la & (c. $1090-1105$ ) & & & Saradasimha & (c. $1090-1105$ ) \\
\hline Ratnapala & (c. $1105-30$ ) & & & Vīrasimha & (c. $1105-25$ ) \\
\hline Ajayapãla & (c. $1192-94$ ) & & & Tejaskarana & [?] \\
\hline Sulakșanapāla & (c. 1196) & & & & \\
\hline
\end{tabular}

An examination of the accompanying map shows that each branch controlled a geographically distinct area (Fig. 1). The Gwalior line, apparently the most powerful and certainly the most important in terms of documented architectural activity, ruled the large tract bounded on the north and west by the river Chambal (ancient Carmanvatì). The Narwar branch apparently controlled the area south of the river Parbati (ancient Pārvatī). This part of the Kacchapaghāta domain perhaps went as far south as Surwāyā, beyond which lay the territories of some later Pratīhära princes (Dvivedi, VS 2004, nos. 627-33). Still further south was the Paramāra kingdom. The river Betwā (ancient Vetravatī) marked the edge of Candella territory in the east; Candella inscriptions are found at Jhansi, Deogarh and Mohangarh (the latter unedited but discussed in Willis, 1993, p. 55). The Dubkund Kacchapaghătas controlled lands up to the Chambal in the west.

\section{Narwar and Dubkund}

The temples at Narwar (ancient Nalapura) have been destroyed, with fragments incorporated into later buildings. Kacchapaghăta monuments in the immediate neighbourhood have been surveyed (Patil, 1952), but have not been subject to systematic study. At Dubkund, there are Kacchapaghāta shrines but these have been reduced to foundations and base mouldings. The ruins were uncovered in the early 1980 s by the Department of Archaeology and Museums, Madhya Pradesh, but a full report of the excavation does not seem to have been published as yet. A long inscription mentioning the
Dubkund Kacchapaghātas has been known since the site was explored in the 19th century; it is dated VS 1145 bhādrapada śudi 3/A.D. 21 August 1088 (Trivedi, 1979-91, 3: p. 530). The inscription, now in the Archaeological Museum, Gwalior, was found in the ruins of a large Jaina temple and records that the building was constructed by an individual named Dāhaḍa and several other eminent Jainas. The construction was also supported by King Vikramasimha who further made revenue donations in the temple's favour. The building consists of a square cloister ( $24.5 \mathrm{~m}$ each side) once edged with shrines carrying roofs of pyramidal form (phämisanā). The doorjambs are richly carved as are the pedestals and canopies. The complex was in an advanced state of ruination even in the 19th century (for illustrations see Luard, 1908, plates 159-62). The plan of the Dubkund temple recalls monuments at Mount Abu and elsewhere in western India. Such influences are also suggested by the remains at Gwalior, as we shall see below. Another inscription at Dubkund was found on the base of a Jaina image (Dvivedi, VS 2004, no. 58). It is dated VS 1152 vaiśākha śudi 5 and mentions a teacher by the name of Śrì Devasena.

The support of Jainism by the Kacchapaghātas raises some hitherto unaddressed questions about this faith in connection with temple patronage. Jainism has been defined by Indologists as a minority religion; its mythology, theology and ritual, aside from resonances with archaic forms of Buddhism, are often viewed as things of strictly special or parochial interest. While it is true that the Jainas have been remarkably careful in preserving their traditions and, like most communities, concerned mainly with their own 


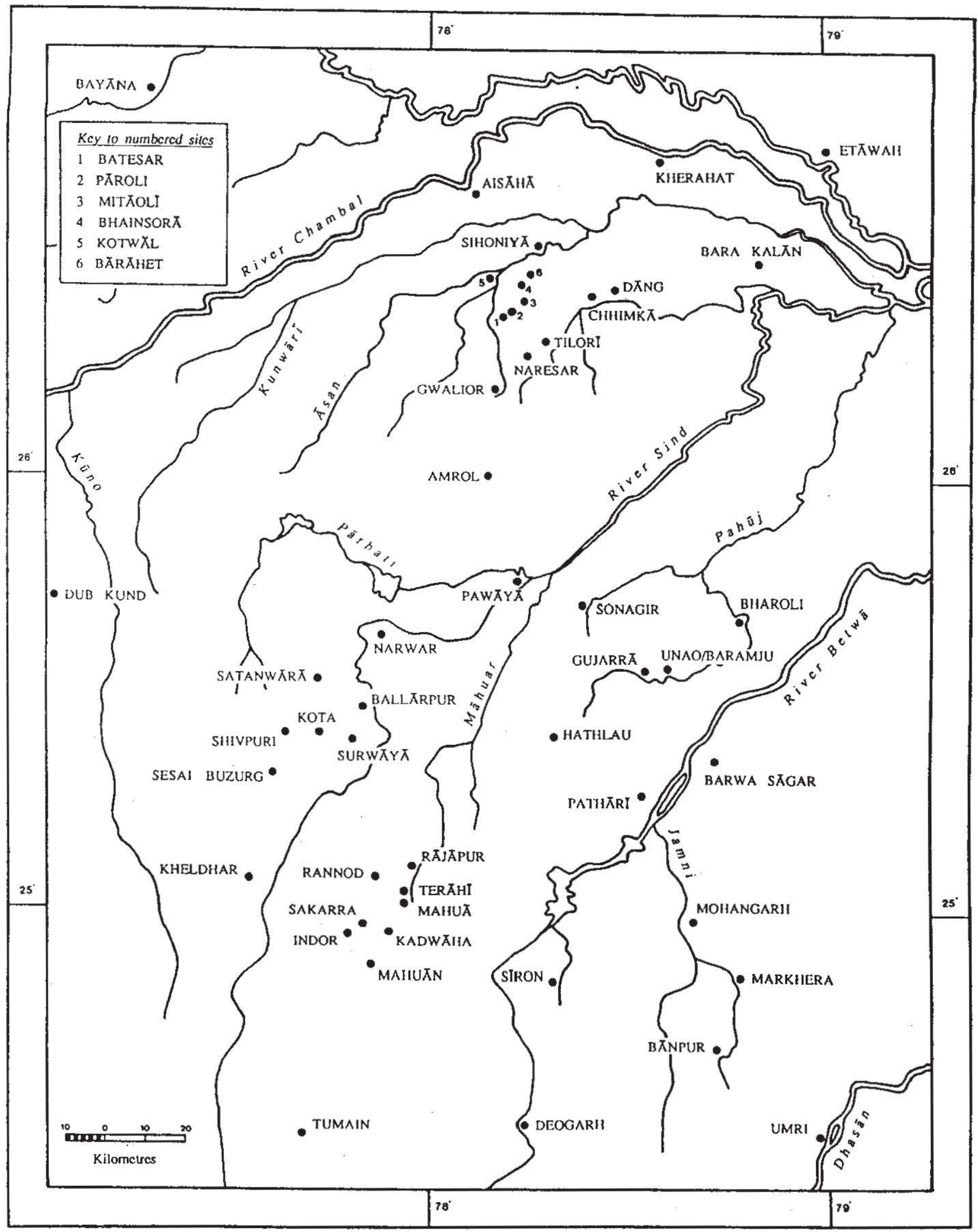

Fig. 1. Map showing the principal sites in the Kacchapaghăta territories. 
affairs, the picture of Jainism as a small sealed world does not square with the fact that several minor Indian dyasties, notably the Gangas in south India, were patrons of significant Jaina monuments. An explanation of this can be found in the beliefs and practices of the faith (Handiqui, 1968; Babb, 1993). We cannot enter into all the details, but the most illuminating feature is that during elaborate pūjās, Jaina worshippers often wear crowns to symbolize their identity with Indra or Indrānī. This seems to be an ancient practice once shared with Buddhism. Setting aside the early Buddhist texts and Kuṣānaperiod images which show the Buddha attended by Indra and Brahma, the first known instance of a devotee actually dressing himself as Indra is Harșa Vardhana (r. A.D. 606-647). This is documented by Xuan Zang in his description of a royal festival at Kannauj (Watters, 1904). It seems unlikely that Harsa's was an isolated case. The worshipping of a Buddha or a Jina would certainly have shown the devotional inclinations of a monarch, but Xuan Zang's account shows that the accompanying pageantry and processions were intended to publicly display the king as Indra. Now it is commonplace in Hindu mythology that Indra is the king of the gods; he occupied this position in Vedic mythology and is still regarded as such today. As a consequence, the ritul actions of an earthly king clothed as Indra were not so much intended to associate the king and the image under worship, but to reinforce the king's identity with Indra. By imitating Indra as an admirer, supporter and helper of the Jina, a king affirmed his privilege to be an Indra among men (narendra). This helps explain why rulers could pay their respects to a tirthamkara without taking on the faith of Jainism, an impossible prospect in any event given the inherent divergence of Jaina doctrine and the responsibilities of kingship. The support of Jainism by the Kacchapaghātas was thus neither an indication of their acceptance of the articles of Jainism nor an indication of their tolerance in the modern sense. Rather, it was a means by which they could publicly invoke their royal status.

\section{Gwalior and Sihoniyā}

The buildings discussed thus far pale beside the major temples at Sihoniyã and Gwalior. Sihoniyā is especially rich in remains of the period, the most magnificent being a large Śiva temple locally designated Kakanmath. The inscription on the Sās Bahū temple at Gwalior (discussed below) provides clues about the authorship and date of this building. The key verse is as follows (Trivedi, 1979-91, 3: p. 542 , v. 11:

\section{adbutaḥ simhapānìanagare yena kāritahl kìrttistamibha ivābhāti prāsādah pārvvatīpatehl/}

In the town of Simhapāniya he [Kïrtirāja] constructed a wonderful temple Pārvatī's Lord, Which shines like a column of glory.

Sihoniyā can be equated with Simhapānīya and the Kakanmațh with the temple of Pärvati's Lord (i.e. Śiva). An earlier verse, which we need not quote for the present purposes, describes Kïrtirāja's exploits against the Paramāras, indicating that the word yena (by him) refers to none but Kirtirāja. As indicated above, this king ruled c. 1015-1035. A date in the first part of the 11 th century for the Kakanmath is confirmed by the general similarity of the building to the Viśvanātha temple at Khajurāho. The Kakanmath stands on a broad terrace and was originally surrounded by at least four subsidiary shrines. The temple-proper consisted of a sanctum surrounded by an ambulatory with balconied transepts; in front of this was a vestibule (antarāla) and a closed hall (güdhamañdapa) with lateral transepts and a porch approached by stairs. The massive lions that flanked the steps have been removed to the Archaeological Museum, Gwalior, and now stand on either side of the museum's entrance building. Many single images have also been taken to the museum or the Archaeological Survey stores on Gwalior fort. The socle (pitha) of the Kakanmath is elegantly moulded and punctuated by niched figures of deities (Fig. 2). The lofty plinth used at Khajurāho has been avoided. The sanctum is girded by the standard podium mouldings, pierced on the north side by a spouted channel (pranala) used to draw libations away from the linga in the cella.

The outer walls, balconies and facing stone of the spire have all fallen away, probably as a result of an earthquake. The only preserved portion of the elevation is that of the sanctum itself. This shows a single row of large images in niches, one on each offset. The images are framed by pilasters and 
miniature arches spewing from the mouths of grotesques (makaratorana). The intervening projections and recesses are filled with nymphs and leogryphs (vyâla). Figural friezes run across the top of the wall. The cardinal projections (bhadra) display larger niches, now empty (Fig. 3). Following 9thcentury conventions, these niches take the form of miniature doors with ribbed awnings and phāmsanāstyle pediments. The sanctum doorway has seven ornate jambs (śäkhâ), one consisting of a large row of deities between two bands of couples. The sill (udambara) carries elephants and recumbent lions, the latter outstanding examples of 11 th-century

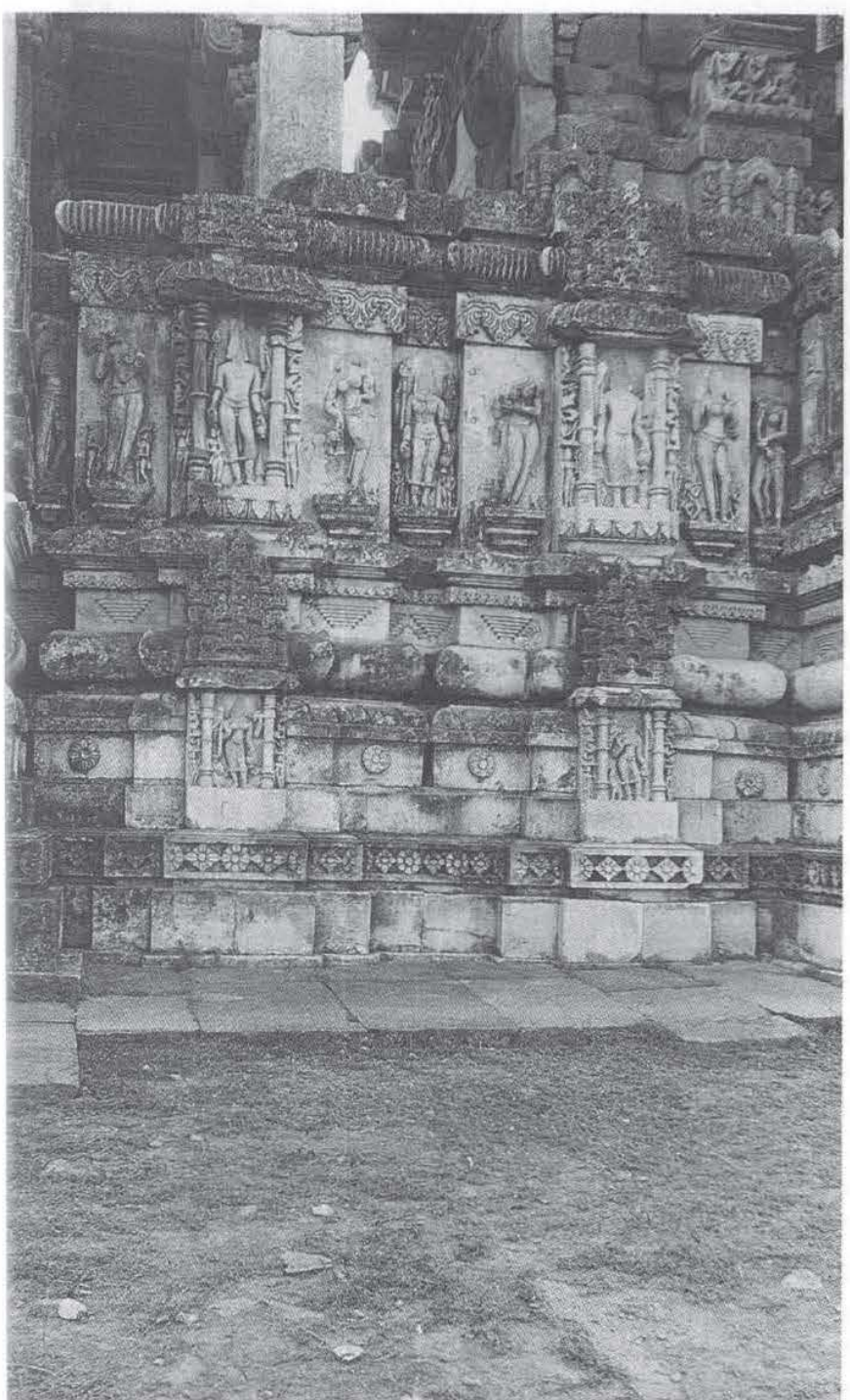

Fig. 2. Sihoniyā, Śiva temple, outer wall of vestibule, first quarter of the 11th century.



Fig. 3. Sihoniyā, Śiva temple, cardinal niche, first quarter of the 11th century. Photograph courtesy of Donald $M$. Stadtner.

sculpture and its tight linear style (Fig. 4). The spire survives to its full height (approximately $37 \mathrm{~m}$ ) but only the rough masonry core and part of the serrated crown (ämalasāraka) have survived. Fallen aedicules $(k u ̄ t a)$ give some hint of the spire's original appearance. As indicated by the Siva temple at Kadwāha (in the so-called Morayat group), these aedicules were probably used at the base of the main spire (mülaśrniga). The vestibule and the hall of the Kakanmath have been shorn of their outer walls, revealing clusters of pillars simply ornamented on the upper quarter and crowned by plain rollbrackets. The central ceiling is lost, but peripheral 


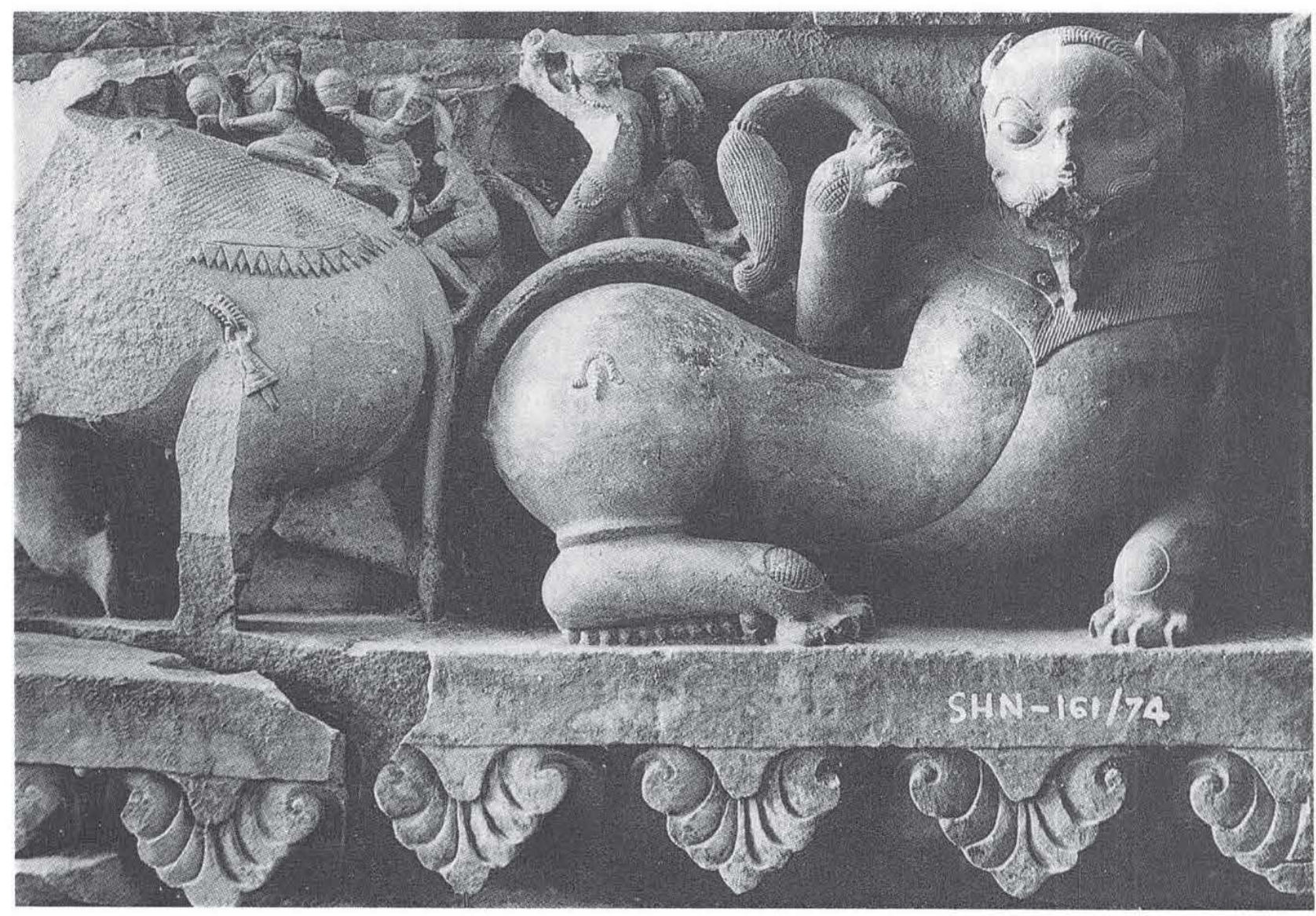

Fig. 4. Sihoniyâ, Siva temple, door sill, first quarter of the 11 th century.

ceilings show designs of cusped coffers. The hall rose to a height of three storeys and was crowned by a bell-finial (ghantā).

The Kakanmath is not the only building at Sihoniyă belonging to the Kacchapaghăta period. Fragmentary sculptures are scattered throughout the village and architectural members indicate that there were once important temples there. Among the many pieces which could be discussed, perhaps the most poignant indicator of what has been lost is the large aedicule (küta) illustrated here in Fig. 5. Compared to the examples at the Kakanmath, just discussed, this küta has a more intricately worked mesh-pattern (jāla), indicating that it is somewhat later in date. The accompanying pillar with festoons and attached figures is coeval. These devices were particularly popular in Gopakșetra during the late 11th century, as will be seen below. In addition to this material, numerous Jaina images can be found at Sihoniyā. Many have been collected in a modern Jaina temple and dharmaśālā to the south of the village, but others were still in the open in the 1980s (Fig. 6). The most venerated temple at Sihoniyan is that of Hanumann. The shrine is a modern construction on a large mound to the north of the village; it rests on old foundations and there are various carved fragments scattered about. The colossal Hanumān image is quite impressive and may belong to the end of the Kacchapaghāta period. The temple of Ambikā Devī, on the western edge of the village, is also of considerable sanctity. This. building is set in a cloistered compound incorporating columns, capitals, brackets and images of various types and dates. The oldest material belongs to the 9 th century. The temple has been heavily reconstructed in a haphazard manner using a variety of antique parts. This is also true of a second shrine in the compound directly adjacent to 


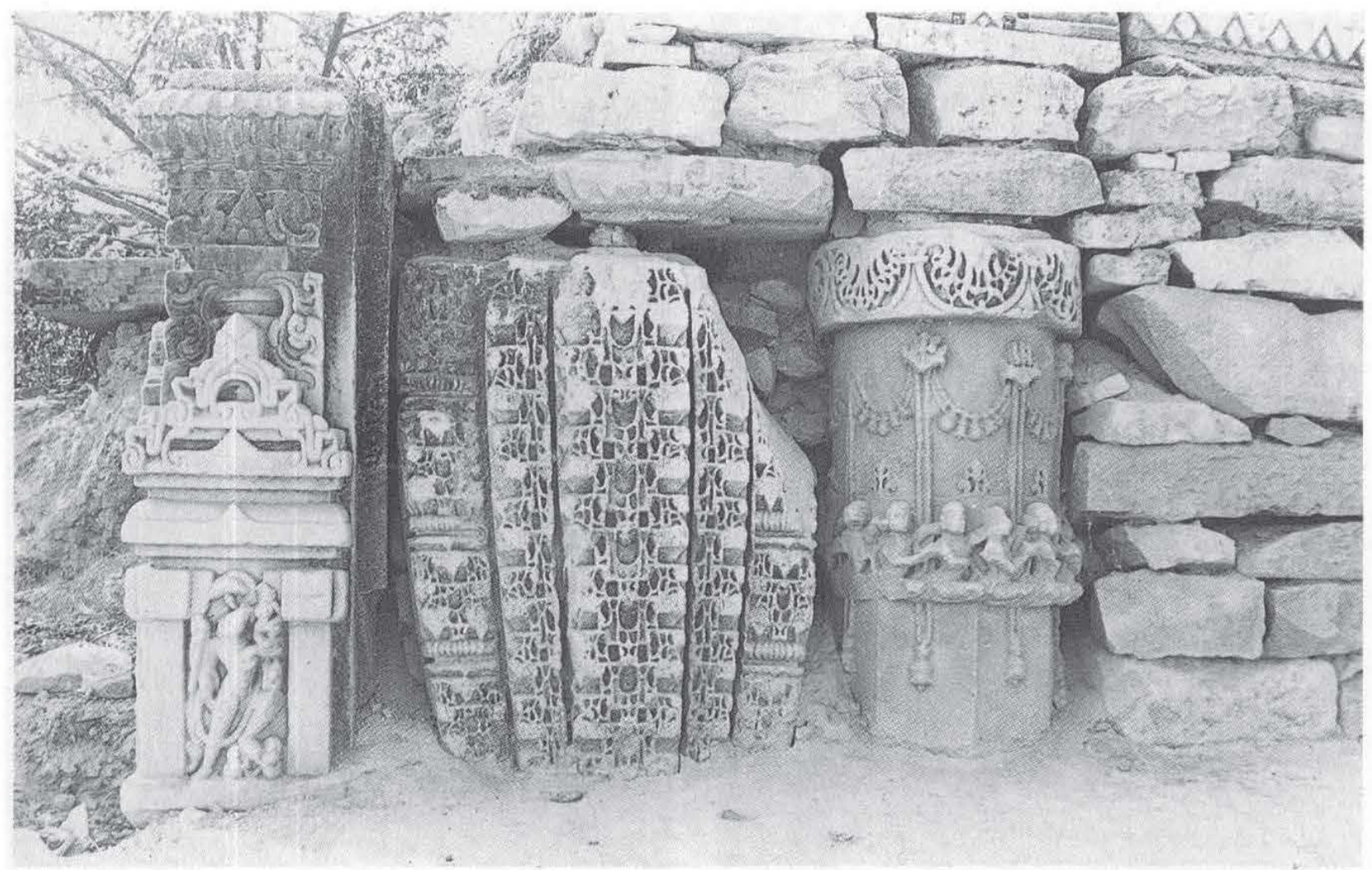

Fig. 5. Sihoniyă, architectural parts, to the left with Varāha image, 9th century, to the right 11th century.

the Ambikā Devi. The entrance door of the second shrine, however, is reasonably well preserved (Fig. 7). Among the many interesting pieces in this complex, a fragment showing a dancing figure may be singled out for attention (Fig. 8). Assignable to the mid-10th century, this piece was originally part of a temple wall (jarighā). The dancer has the twisting dynamism often associated with later Indian art, but the sculptor has happily avoided the ugly distortions and fragmented modelling of the body which is found in many of the female images on the Lakșmanà temple, Khajurāho.

Sihoniyã is not far from Gwalior and in that great fortress there are two Vaișnava temples which mark the culmination of the Kacchapaghāta style. Popularly known as Sãs Bahū ("daughter- in-law and mother-in-law"), the larger temple preserves long inscriptions in the porch recording that the building was commenced by King Padmapāla (c. 1085-90). One of the key verses in the dedicatory inscription is as follows (Trivedi, 1979-91, 3: p. 543, v. 26): prajābharttrā tena kșititilakabhūtena [bha]vanam harerddharmmajñena tridasasa[drșā]/käritam adahl

vadāmyasyo[ccaistvami] katham iva girā yasya śikharam samārūḍhạ̣ simho mrgam iva [mrgànika]stham aśitum \|

This supporter of his subjects, an ornament of the earth, who knew the law (and) who was like the gods, commissioned this edifice of Hari.

How can I possibly tell you of its height with words? The lion who has mounted the spire means to devour, it seems, the deer in the moon.

The inscription informs us, however, that Padmapāla died before completing the temple (v. 30) and that Mahipāla, as soon as crowned, vowed to finish the building (vv. 69-70). This he did, as well as providing numerous endowments, gifts and valuable treasures. The temples contained several sacred 


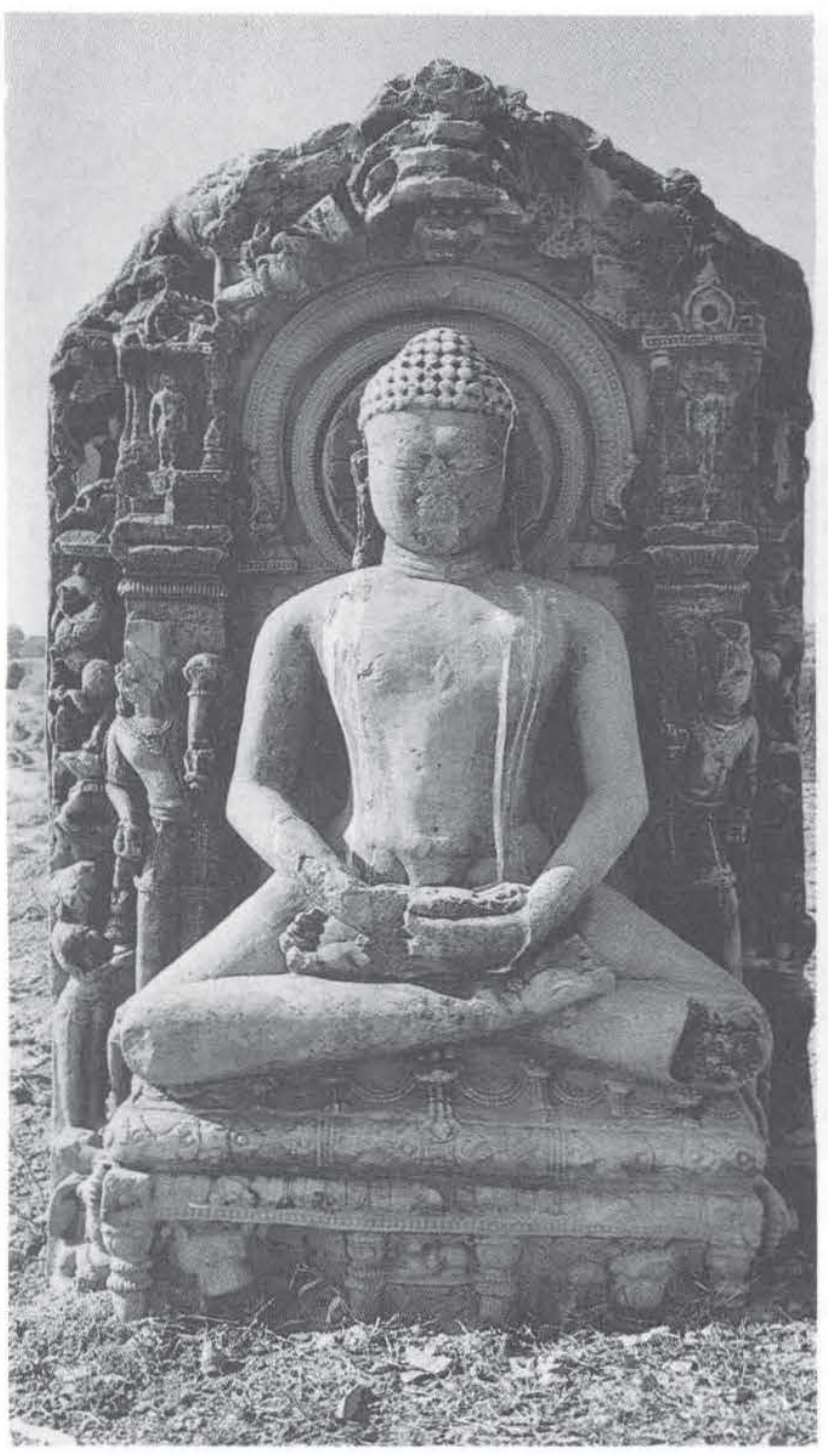

Fig. 6. Sihoniyã, seated tïrthamkara, 10th century.

images, but the most important was Śrī Padanātha (i.e. Vișnu) named in honour of king Padmapāla.

The larger Sās Bahū temple comprises a sanctum, vestibule and closed hall (güdhamandapa). Only the much-restored core of the sanctum remains, the outer walls and superstructure having disappeared. The hall, however, has been preserved and exhibits grand dimensions and an unusual design. Rising to a height of $24.4 \mathrm{~m}$ in three-storeys, it is surmounted by an elaborate pyramidal roof covered with miniature spires (samvaranâ). This is different from Khajurāho where roofs with simple slabs (phämsanâ) were preferred. The north and south sides have broad pillared porticoes while the

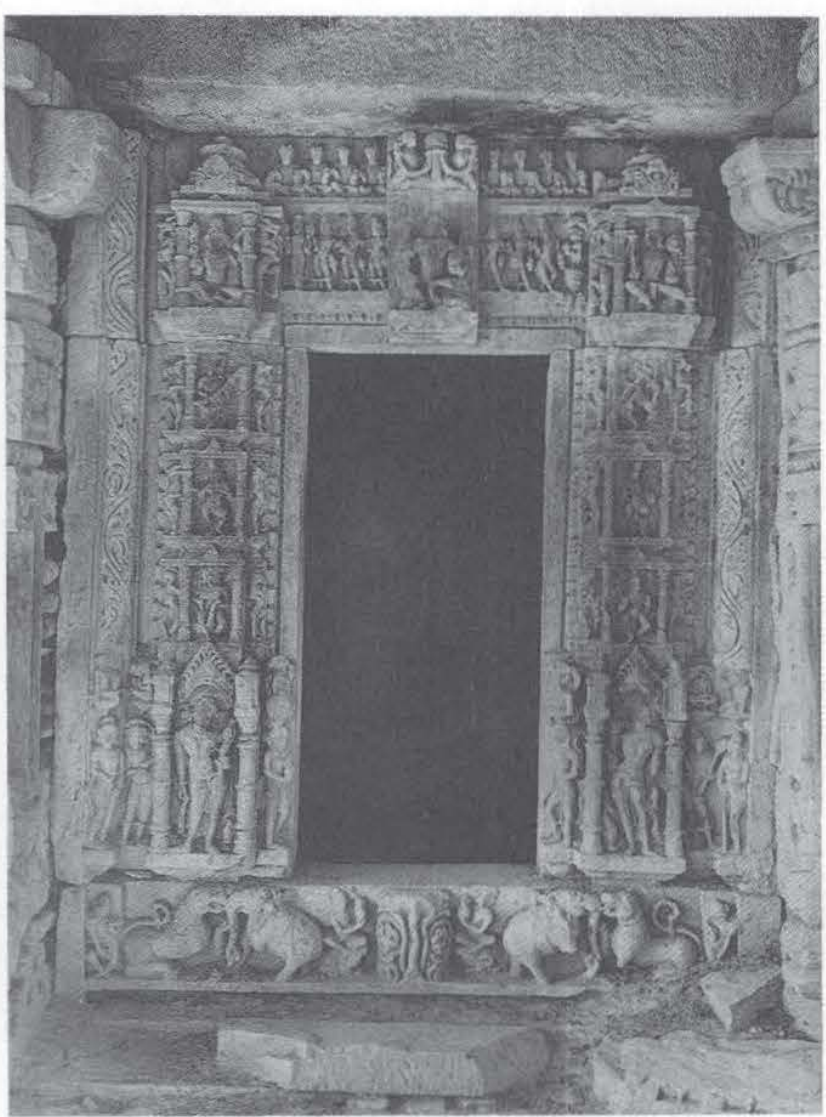

Fig. 7. Sihoniyã, Ambikã Devĩ temple, shrine entrance door, 11th century.

east side has a large two-storeyed porch. This porch shelters the inscriptions and the main entrance (Fig. 9). With its spiral columns, profusion of jambs, complex sill (udambara) and over-door (uttarānga), it is the superlative example of the mature Kacchapaghāta idiom. The interior is a spacious twelve-sided hall with an enormous circular ceiling of concentric rings, supported by four massive piers. In the corners of the hall are shrines, now empty. These represent an internalization of the pañcãyatana or quincunx plan, an arrangement seen earlier in the Gwalior region, most notably in the hall at Pārolī, a building that can be placed in the early 10th-century prior to the rise of Kacchapaghāta power. The images on the exterior of the Sās Bahũ are defaced, but enough has been preserved to show the remarkable decorative vitality of surface, with the figures combining tightly modelled forms with agitated linear movement (Fig. 10). The interior retains much of its original appearance with stencillike ornamentation covering every available surface. 


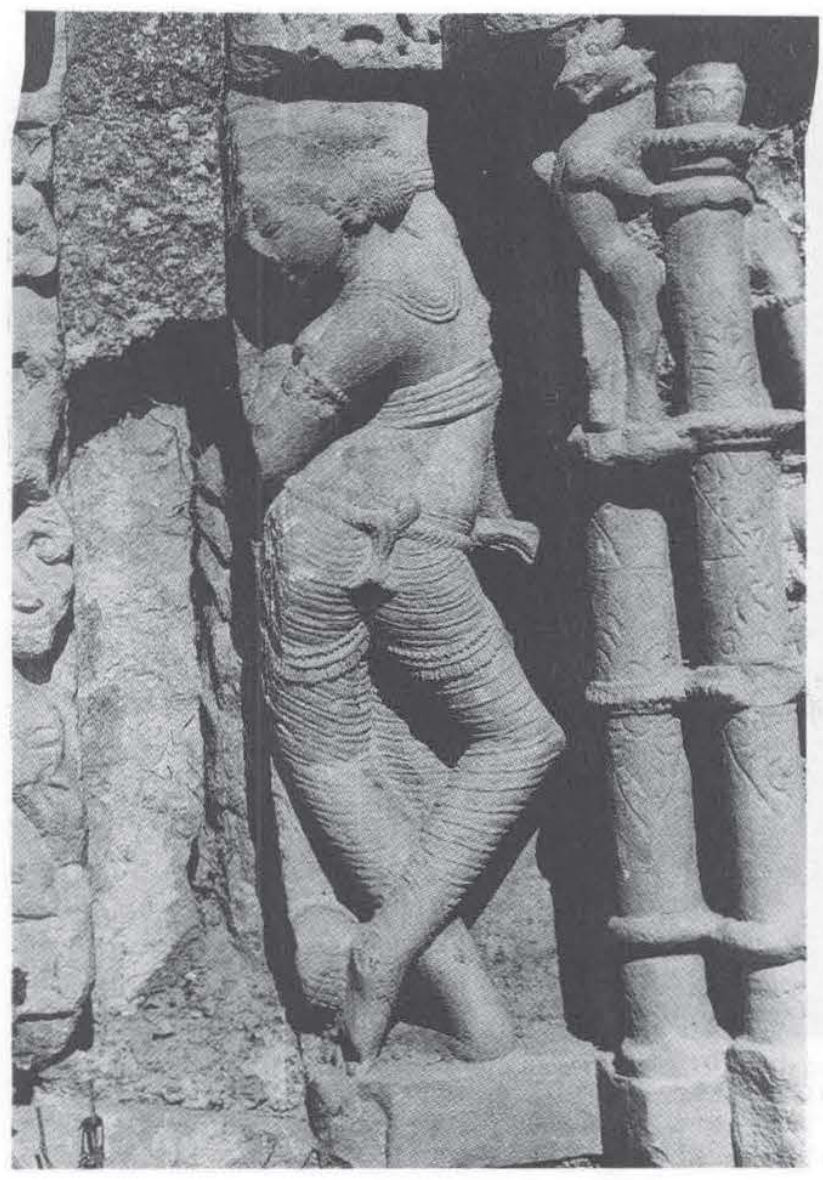

Fig. 8. Sihoniyā, Ambikā Devĩ temple, dancing figure, 10 th century.

The temple has been subject to extensive and somewhat intrusive restorations. Large beams have been added inside for support and, on the exterior, the mouldings have been extensively rebuilt in many places. In addition, some of the exterior walls have been completely rebuilt and alien pieces (some dating as early as the 9th century) have been introduced.

The smaller Sās Bahū temple is better preserved. It consists of a porch, open hall (rangamandapa) and sanctum door-frame. The sanctum itself has completely disappeared. This temple is raised on an ornate socle (pitha) crowned by running friezes of elephants and human figures (Fig. 11). Mouldings such as these are not seen earlier in the Gwalior region. In the 9th century, temples generally lacked any kind of plinth save for square slab-mouldings (bhitta). Even at Sihoniyā the plinth is relatively low and is constituted so as to resemble a vedíbandha (Fig. 2). The mouldings that

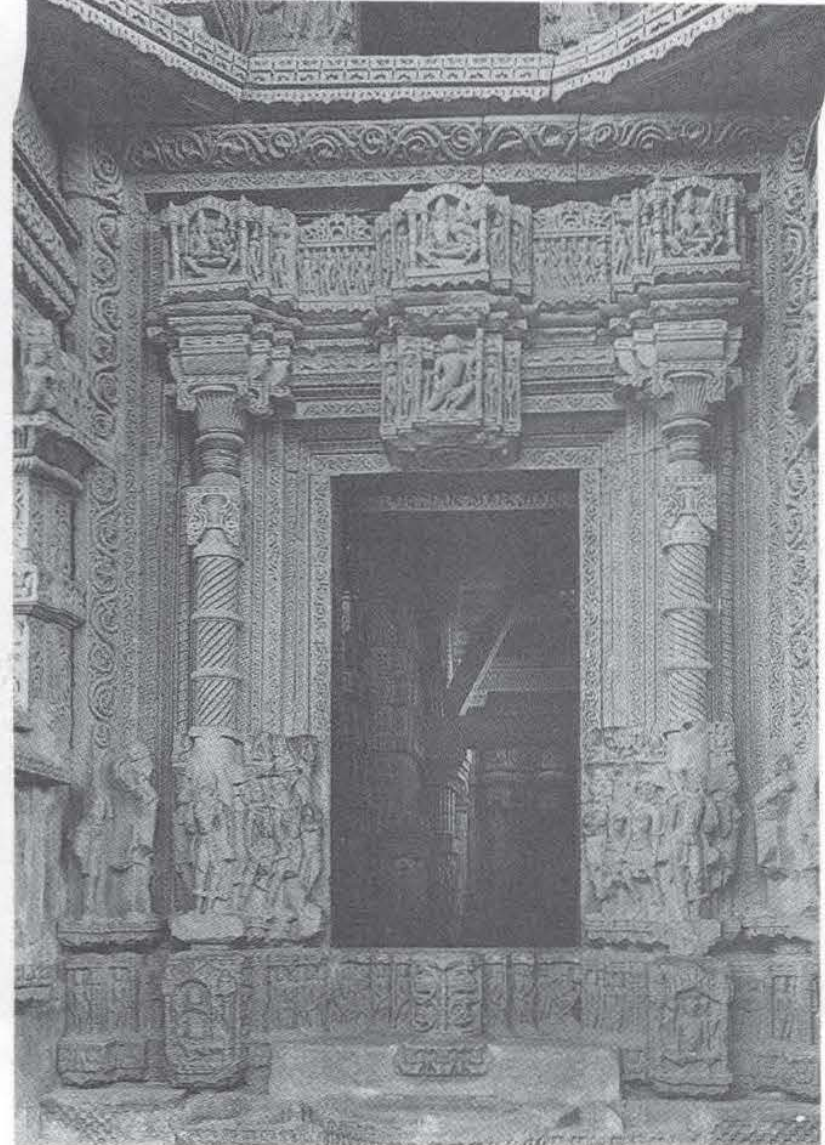

Fig. 9. Gwalior fort, larger Sās Bahū temple, entrance door, dated by inscription VS 1150/AD 1093-94.

appear in the Sās Bahū may represent influence from western India, where similar forms are found. However, in view of the fact that so many buildings have disappeared we must be extremely cautious with such observations. Above the mouldings is a parapet wall with a sloping seat (kakșāsana). On the seat are dwarf pillars which support a ribbed awning. The roof is a smaller and better-preserved example of the type used on the large temple; the same is true of the domical ceiling within. The porch and interior have highly ornate pillars embellished with figures. This use of attached figures might seem to be a Kacchapaghāta device, but a similar configuration is found on one of the columns in Quwwāt al-Islām mosque at Delhi (Fig. 12).

The idol chamber of the larger Sās Bahū temple has been virtually destroyed, though some modern attempts have been made to reconstitute the outer walls in a rough-and-ready fashion. The cella of the 


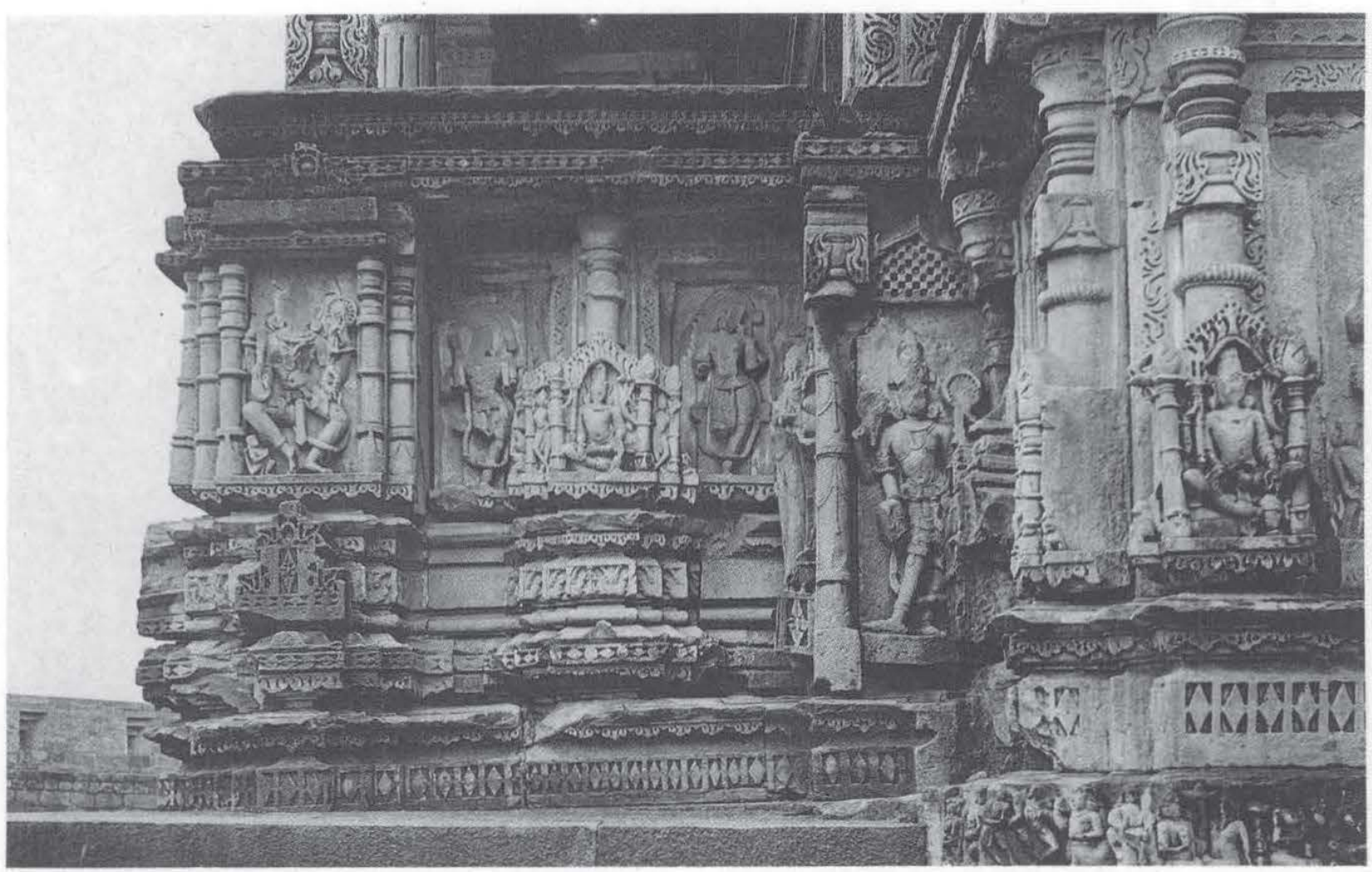

Fig. 10. Gwalior fort, larger Sãs Bahū temple, detail of exterior wall, dated by inscription VS 1150/AD 1093-94.

smaller Sās Bahū has, of course, completely disappeared. The destruction of these parts is customarily written off as an example of religious fanaticism. While it might seem relatively innocuous to regard the Sās Bahū temples as expressions of Vaisnava piety and their desecration a measure of religious intolerance, this kind of interpretation is a secularized critique that separates religion and polity to the advantage of the former. At its worst, this interpretation flies in the face of the inscriptional evidence and is an aggressive attempt to deprive the monument of historical content.

While we cannot deal with these issues in detail due to limitations of space, it is worth touching on the matter in view of its contemporary.relevance. The dedication of the larger Sâs Bahũ to Padmanătha in honour of king Padmapāla demonstrates that the Kacchapaghăta kings equated themselves with the deity they had establisheđ in the temple. In this the Kacchapaghantas were not alone, a fact documented by examples throughout the subcontinent (see Dirks, 1987; Inden, 1990, pp. 228-62; Willis, 1993). From the 7th century, and more particularly in north India from the 10th, ruling kings, as devotees, intermingled their personalities with those of specific gods. In the first place, kings shared their names with temple deities, a metaphorical likeness amplified by the eulogistic epigraphs which compared their attributes and achievements. A fuller sense of the relationship is provided by the royal rituals carried out at Vijayanagara (Stein, 1983). Specifics of these rituals, particularly the mahänavamī festival, were unique to South India in the 15 th and 16th centuries, but I do not think it is unreasonable to infer from this later material that the Kacchapaghăta king was the principal devotee and that a centrepiece of ritual in the larger Sãs Bahū was the king's worship of Padmanātha. Extending this inference we might suggest that the king entrusted his regalia to the god during worship and his annual lustration (abhiseka). Such acts, or at least ones broadly similar 


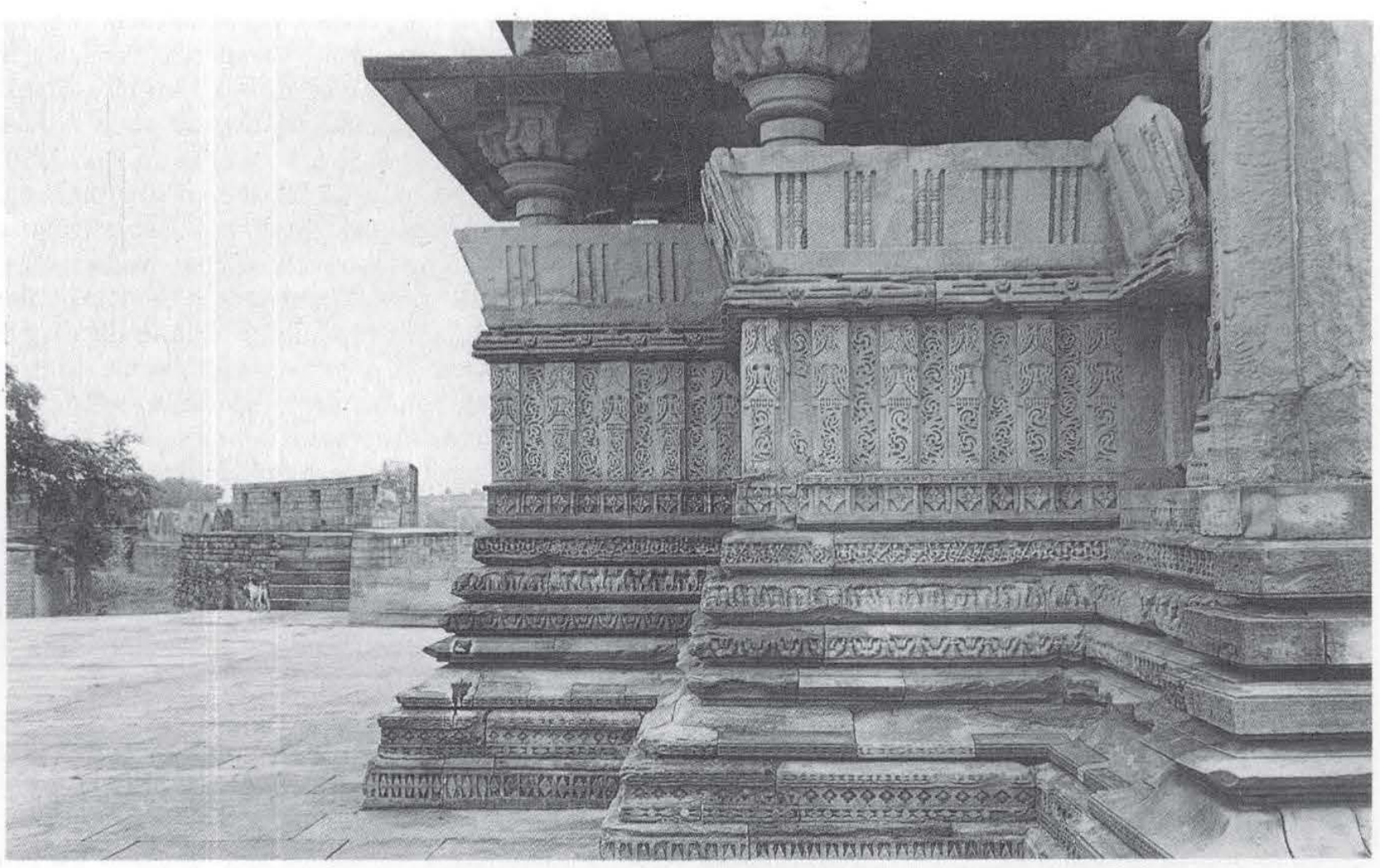

Fig. 11. Gwalior fort, smaller Sãs Bahũ temple, plinth and parapet wall, datable by inscription VS 1150/AD 1093-94.

to them, were the instruments through which the Kacchapaghâtas constituted and maintained their power. In this light, the motivation for the destruction of the Sās Bahū sanctum is reasonably clear. Defeat of the dynasty was signalled not only by military reversals in battle, but by the destruction of the institutions and ultimately the buildings through which the monarchs sought to construct their legitimacy. The demolition of the sanctum and the smashing of the deity quite literally decapitated the Kacchapaghâta regime. The temple-hall at Gwalior thus represents a headless corpse, left behind as a poignant sign that the old dispensation had been brought to an end. Perhaps nothing else so clearly indicates that the arts of peace and war were intimately connected, and that the historical process through which this building has passed recapitulates the metaphysical truth, oft-heard in India, that creation contains the seeds of destruction. Certainly the desecration of temples in India is associated most commonly with Mahmūd of Ghazni and his successors in the Delhi sultanate, but these destructive acts must be put in the context of the Islamic practice of demolishing the monuments of earlier Islamic regimes and the long history of temple looting within the Indian tradition itself (Davis, 1993).

The historical sketch given above illustrates the centrality of the Sās Bahū temples and shows why they were singled out for destructive attention. Other buildings were less important and are consequently in a better state of preservation. The most instructive example is a ruined temple near the Surāj Kund on Gwalior fort (Fig. 13). This gives some indication of the appearance of the missing parts of the Sās Bahū temples. The lower mouldings of the plinth (pitha) have been stripped away, but the inverted cyma (jädyakumbha), pointed arris (karnikâ) and band of grotesques (grasapattiti) are reasonably well preserved. Above these mouldings rises a prominent socle (vedíbandha). The treatment of these forms diverges significantly from Khajurāho and indicates that distinct architectural practices were maintained in Gopakșetra under the 


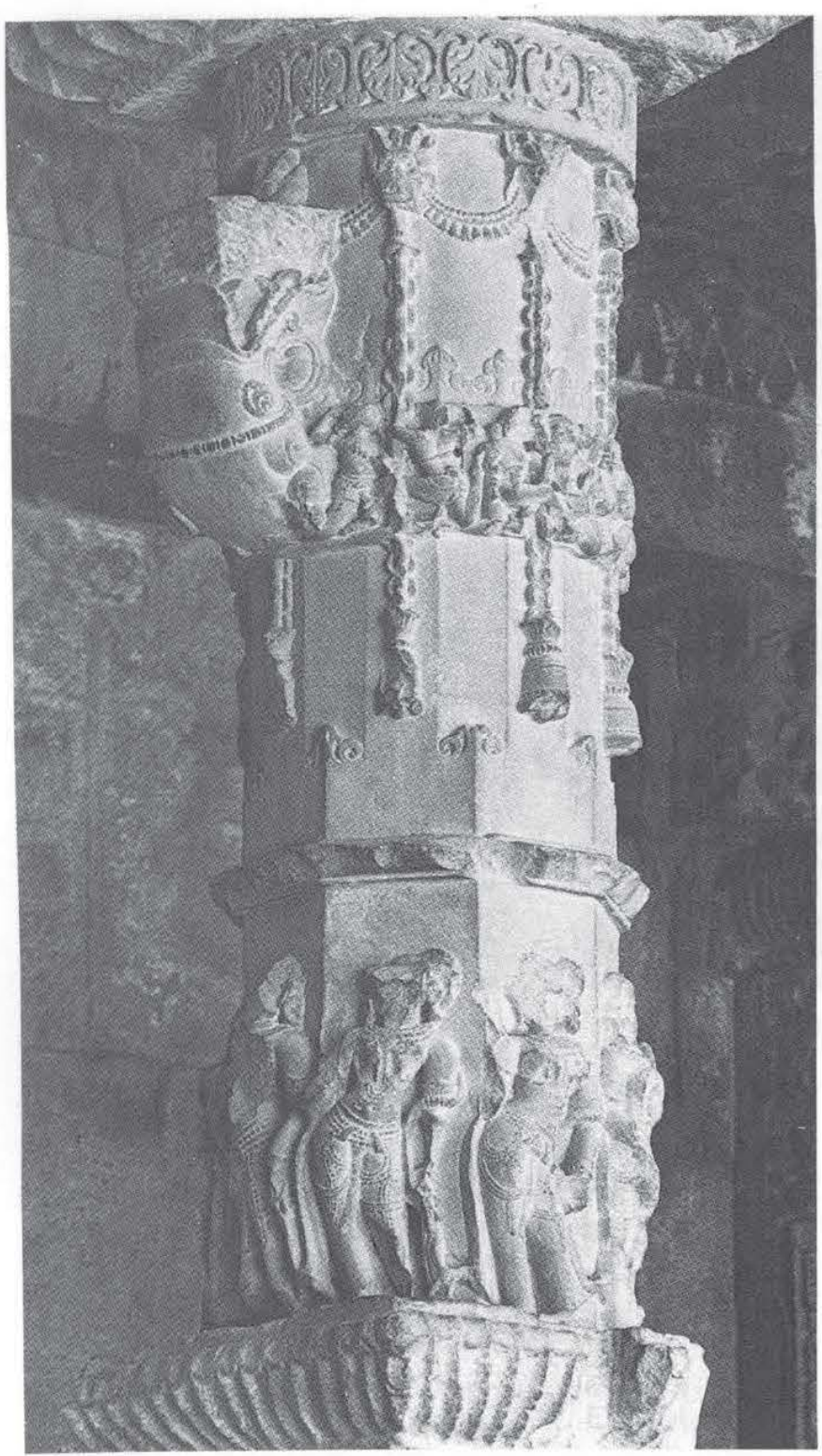

Fig. 12. Delhi, Quwwāt al-Islām mosque, pillar, 11th century.

Kacchapaghätas. In the first case, the vedībandhamouldings do not carry image niches, but flaring appliqués with spade-shaped tips. Nothing of this sort is seen in the Khajurāho temples. Secondly, the foot-moulding is very tall and provided with a cornice-like cap. This recalls the lotus-cap employed on the Kakanmațh at Sihoniyā. The kalaśa (torus) is no longer prominent, but becomes one of a series of string courses (mañcikâ) placed below the wall and image niches. The variety of these mouldings and the depth of the recesses between them is again at variance with Khajurāho standards. Particularly telling is the fillet on the edge of the torus, a virtual signature of the mature Kacchapaghāta style. Above the string-courses is the wall-section (jainghā), perhaps the most unusual feature of this building. The degree of architectural clarity is particularly evident when we juxtapose these plain walls against the tightly packed tiers of sculpture in the Khajurāho temples. The absence of sculpture allows the offsets to be developed into pilasters, a theme that is carried into the entablature (varandika ) where the pendant-like leaves represent capitals. Also of note in the entablature are the mouldings constituted as a vedibandha. In 7th-century architecture, elements of the podium were often reproduced in the upper parts of the spire to represent an elevated altar or uttaravedi, but the preservation of this theme at such a late date is unusual. The superstructure of the Gwalior temple has fallen, but it may be assumed that it was some sort of multi-spired sekharī, perhaps akin to the example surviving at Kadwāha. Fragments which may have come from this superstructure, or from others of the same period, can be found on Gwalior fort. The Kadwāha temple, it should be noted, alerts us to the fact that plain walls were not a uniform practice in the 11th century, but represented one of several options which architects could pursue.

A number of shrines and temples in the countryside around Gwalior are related to those just discussed and further illustrate the variety of architectural forms in Kacchapaghāta territory. The most interesting, at least among those I have been able to locate, are found in the vicinity of Pārolī, a village of considerable antiquity. It is perhaps not out of place to note that Părolī (or Pāroli) was known anciently as Paḍhâvali, a name testified by an unpublished hero-stone inscription (now in the Archaeological Museum, Gwalior). In the jungle near Pāroli is the site of Batesar, a name derived from the old temple there dedicated to Batesar Mahādev. The path between Batesar and Pārolĩ is dotted with many ruined temples and a significant number of them belong to the Kacchapaghăta period. A ruined hall is the most impressive of the group. It is cruciform in plan like the smaller Sās Bahū and has closely related pillars internally (Fig. 14). The mouldings, however, are less elaborate while the parapet pickets (stambhikâ) and recessed 


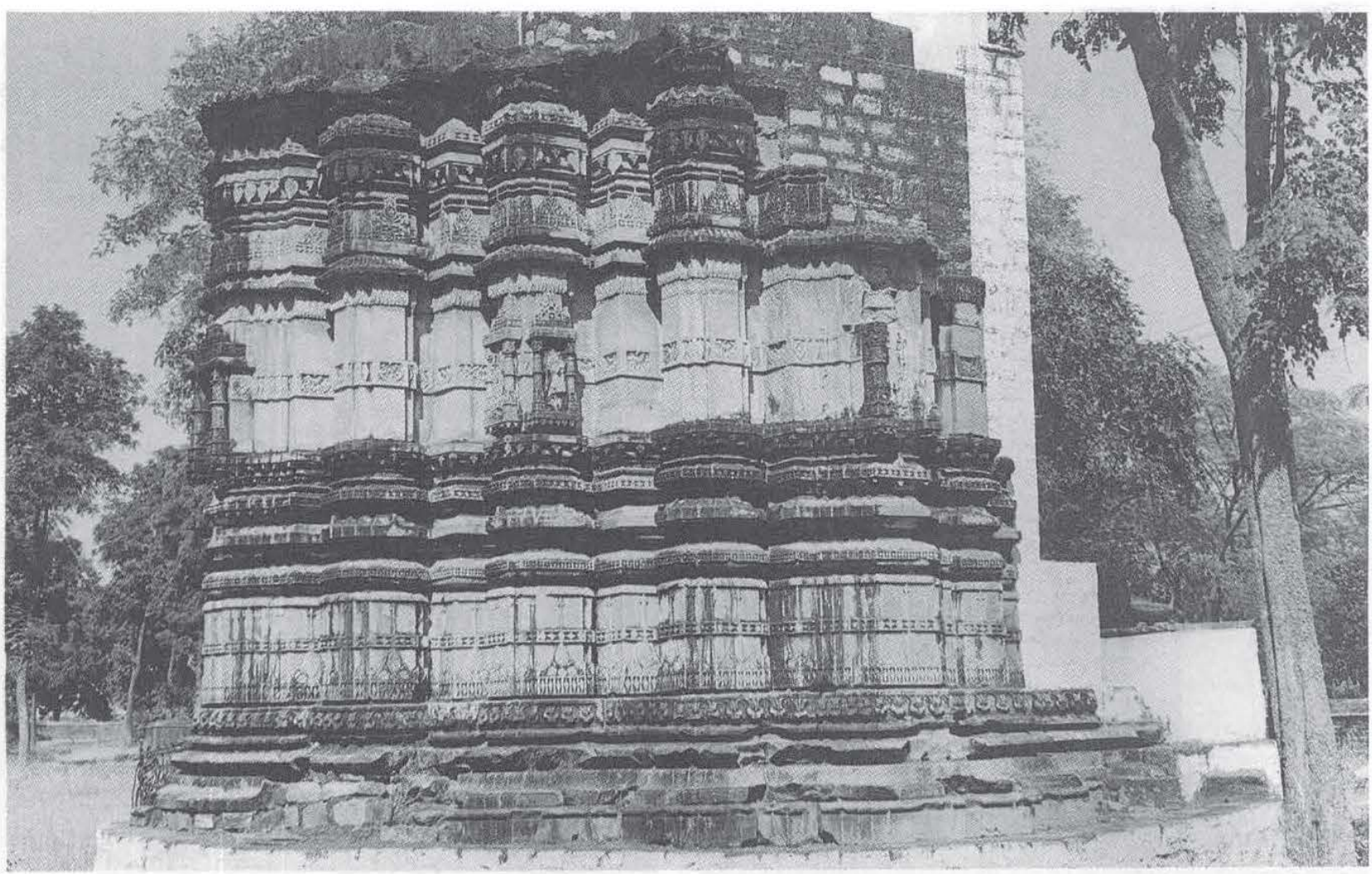

Fig. 13. Gwalior fort, ruined temple near Surãj Kund, 11th century.

panels (phalaka) lack stencil-like patterns. The door is likewise less elaborate. These points suggest that the Pārolī ruin is earlier than the Sãs Bahū temples; a date in the mid-11th century seems likely.

Other buildings also document mid-11th century architecture, albeit at a more humble level. The structure illustrated here in Fig. 15 may be taken as representative of the many shrines which have survived in the general vicinity of Pârolī. This temple illustrates the later history of a type now generally known as mandapikā (Meister, 1976). While we shall use the term mandapikā here, it must be noted that the meaning of the word was not so restricted in epigraphic usage as it has recently become in arthistorical parlance (see Sircar, 1966, s.v.). A mainstay of shrine architecture in central India from the 7 th century, the mandapika-type was first characterized by walls composed of alternating pilasters and slabs. Perhaps derived from post-and-plank construction in wood, the mandapika enjoyed its heyday in the 8th and 9th centuries. The Kacchapaghāta example at Păroli retains the essential features of the type, notably receding slabs and projecting pilasters; the niches are also crowned by simple pediments (udgama) in the traditional fashion. The pilasters, however, are stripped of ornament and the pediments treated with greater flatness than in earlier times. A second shrine a few kilometres southeast of Pāroli is of the same type (Fig. 16). This building introduces guardian figures on the corners, an arrangement derived from the iconographic programme of latina temples. A variation of this is seen in a third shrine which has unusual niches straddling each corner of the structure. Directly beside this shrine is a large figure of a Jaina tirthamkara, one of the best preserved 11th-century sculptures in the area (Fig. 17).

The subsequent development of mandapikä architecture is documented by a Vișu temple at Tilori (Fig. 18). This building is preceded by a ruined hall of which only the pillars and lintels remain; one 


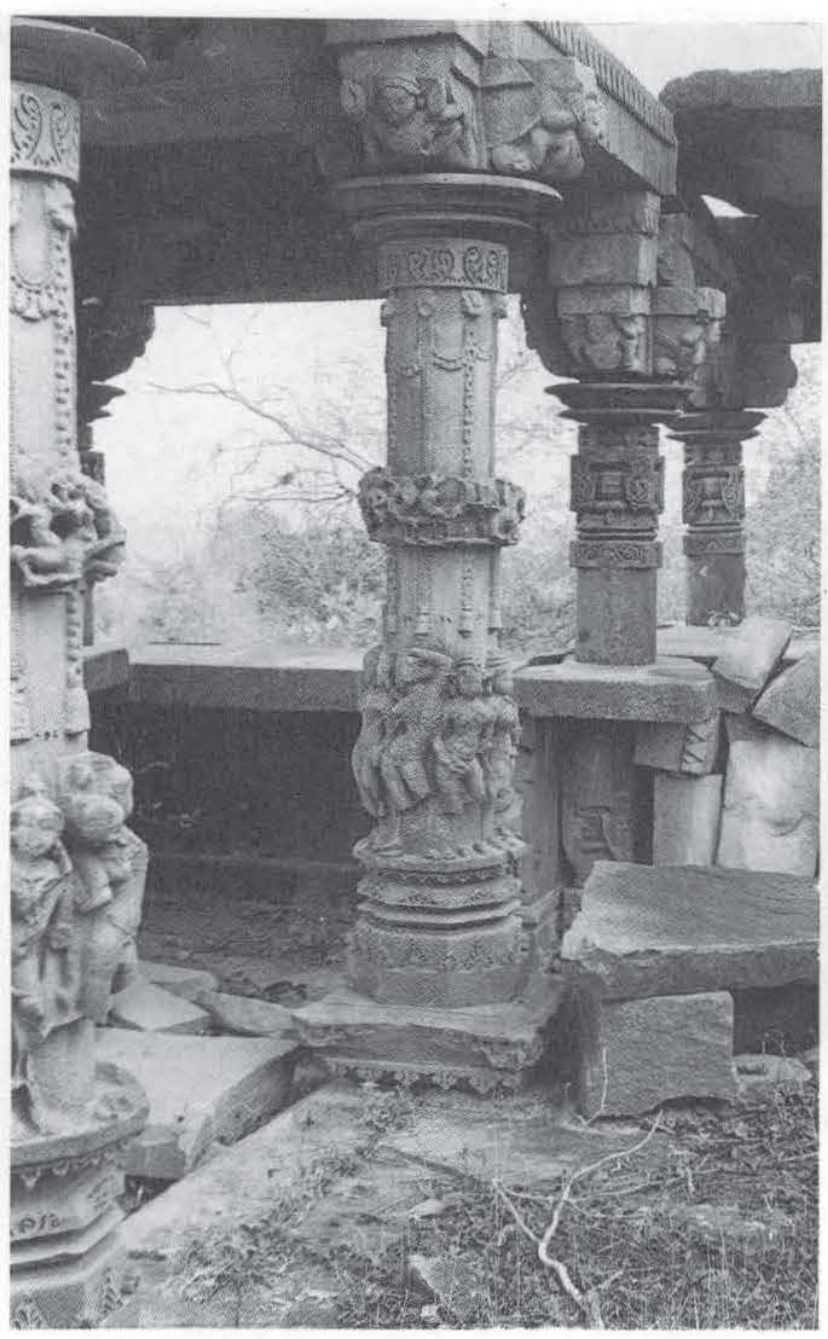

Fig. 14. Pãrolī, ruined temple hall, interior, mid-11th century.

pillar carries an inscription of a later date (Dvivedi, VS 2004, no. 306). The temple has a large platform (jagati $)$, now partially disturbed. The exterior walls of the shrine-proper are composed of a medley of ornamental pilasters, chequered recesses and niches with pediments. The pilasters have the flat stencillike patterns of the larger Sãs Bahū temple, while the niches retain pediments of an older variety. On the corners (karna) and vestibule wall (kapili) the niches have been cut to accommodate the required space, a late and awkward rendition of the halfcandraśâlā motif that is found in temple architecture from the 7th century. The door of the Tilori shrine continues the configuration seen earlier at Pāroli

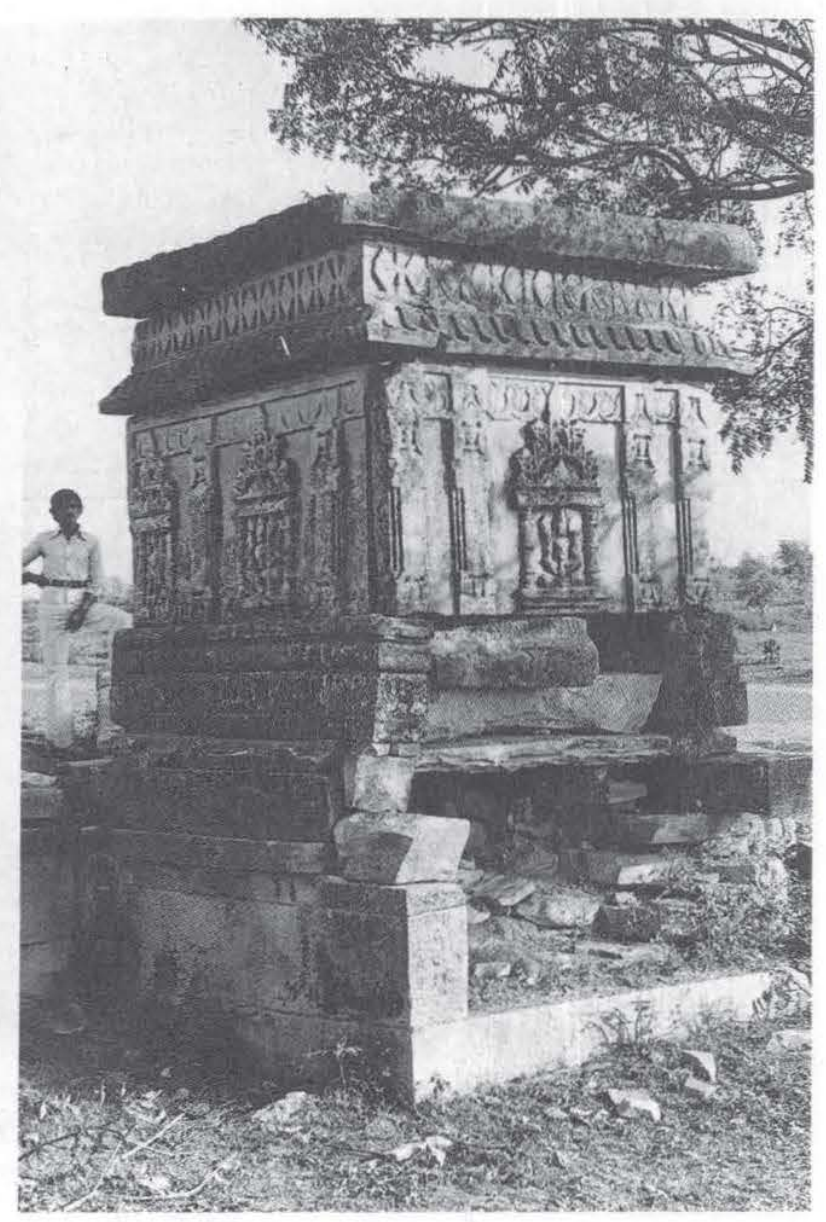

Fig. 15. Pârolī, shrine of the mandapikã, mid-11th century.

(Fig. 19). That this temple is later than the mandapika-shrines of the mid-11th century is not likely to be argued. While the decorative surface is analogous to the Sās Bahū temples, the shrine has none of their considered architectural proportion or decorative panache. There are, in fact, no architectural features derived from the Sās Bahũ project; all the forms are drawn from a humble architectural repertoire that seems to have maintained its basic vocabulary apart from the ambitious monuments of the Kacchapaghāta rulers. This indicates, in my view, something of the internal autonomy of ancient Indian society, where local practices and traditions were allowed to continue without interference from the centre, even a centre so close as Gwalior. 


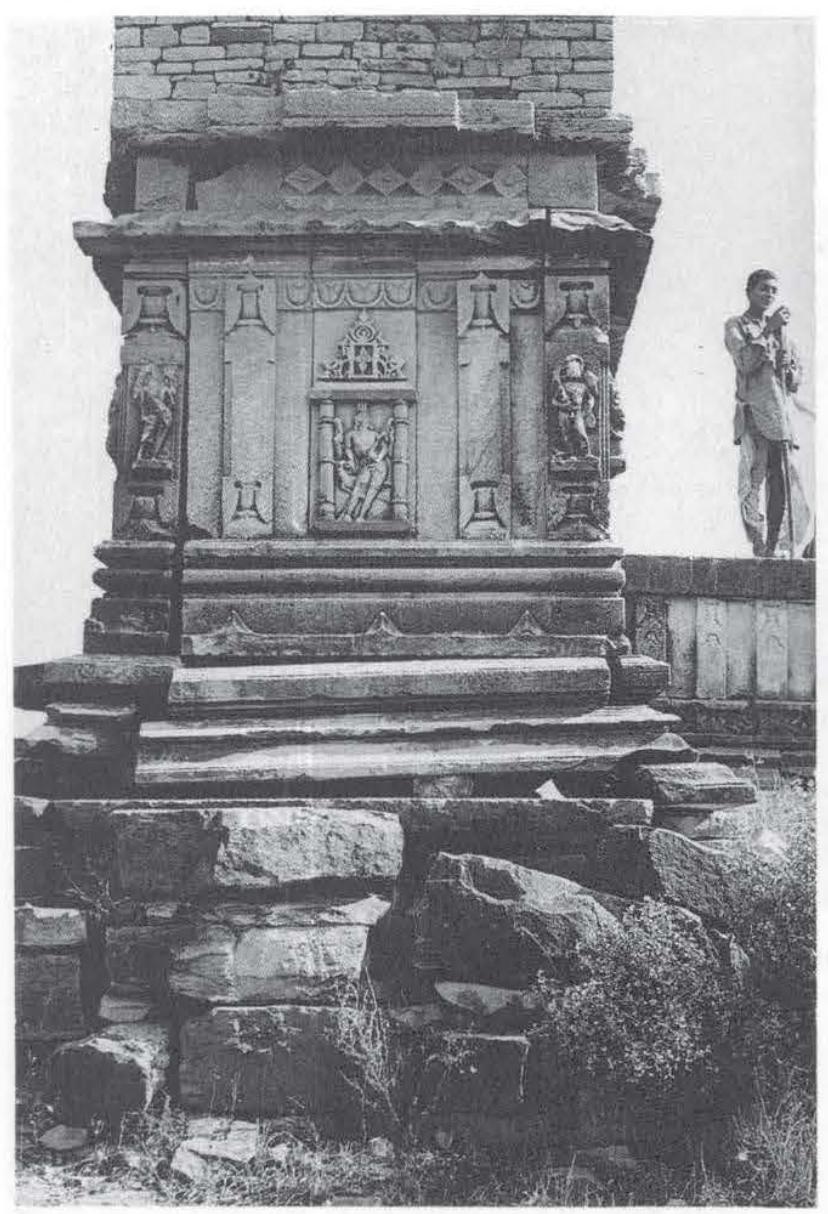

Fig. 16. Pârolĩ, Śiva temple, mid-11th century.

The dynastic history of the Kacchapaghātas after the late-11th century is unclear (Trivedi, 1980), but enough is known to provide a tentative outline of architectural developments. We have an inscription of Ratnapāla (c. 1105-30) mentioning the foundation of a Siva temple, but this record has not been properly edited (Sinha, 1980). When discovered, the inscription was built into the curtain wall of the fort near the Săs Bahū temples; it was removed before 1980 to the Archaeological Survey of India stores (near Mān Mandir). The building to which this inscription refers seems to have disappeared, but a ruined structure of approximately the same period is located at a central point on Gwalior fort. This building, in its current state, consists of three superimposed sanctums. It was probably crowned by a multispired superstructure and surrounded by an ambulatory resting on a substantial moulded plinth. There may have also been a hall, but excavation would be necessary to confirm this. Superimposed sanctums are unusual but not unknown in Indian architecture. The most famous instance is the Vaikuntha temple at Kãñchī, but the Sās Bahū hall provides a closer parallel with its door-like opening above the main entrance (Fig. 9). A date in the 12 th century for the ruin is suggested by the general flatness of the offsets, the reduction

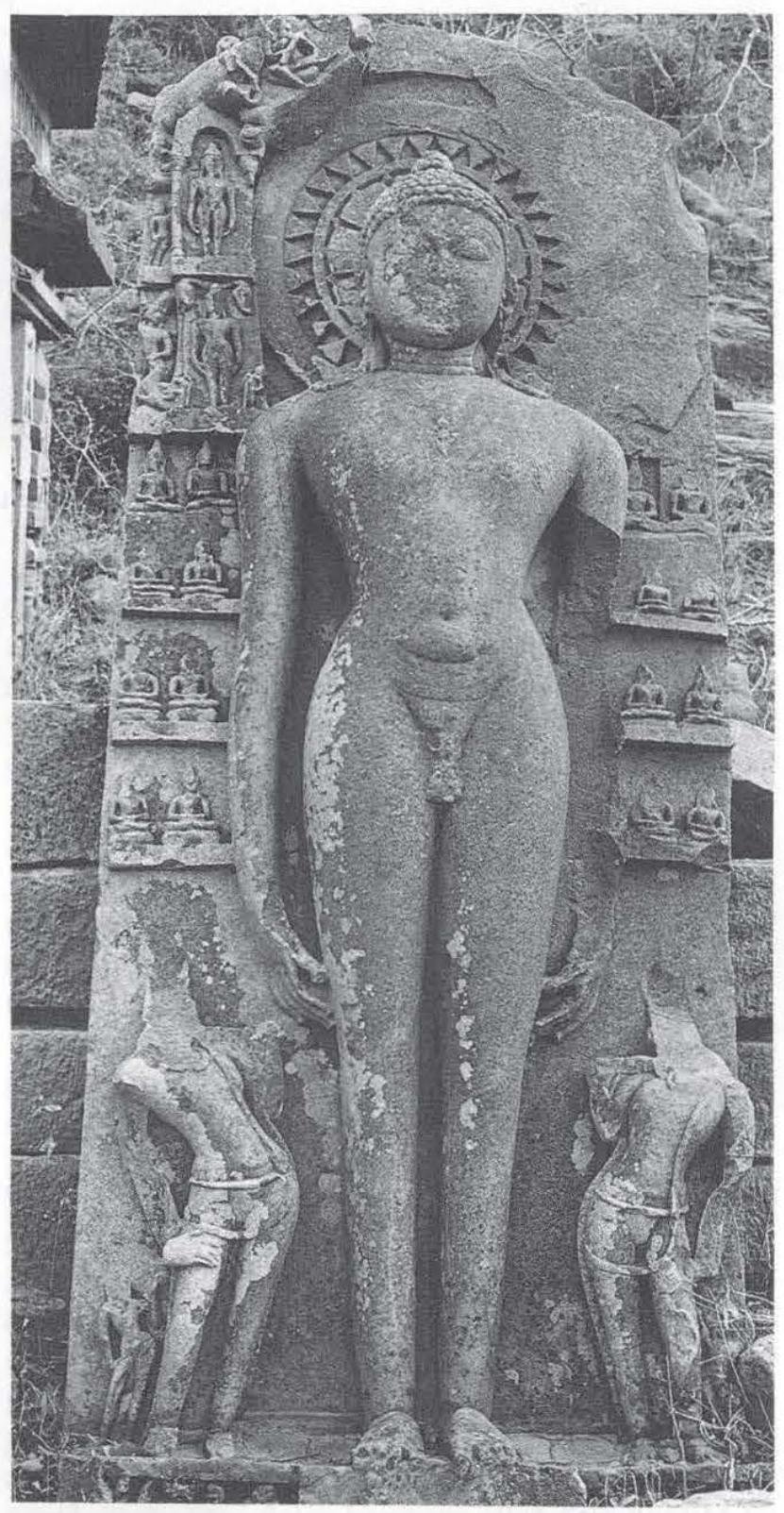

Fig. 17. Pãrolī, standing tîrthamkara image, 11th century. 


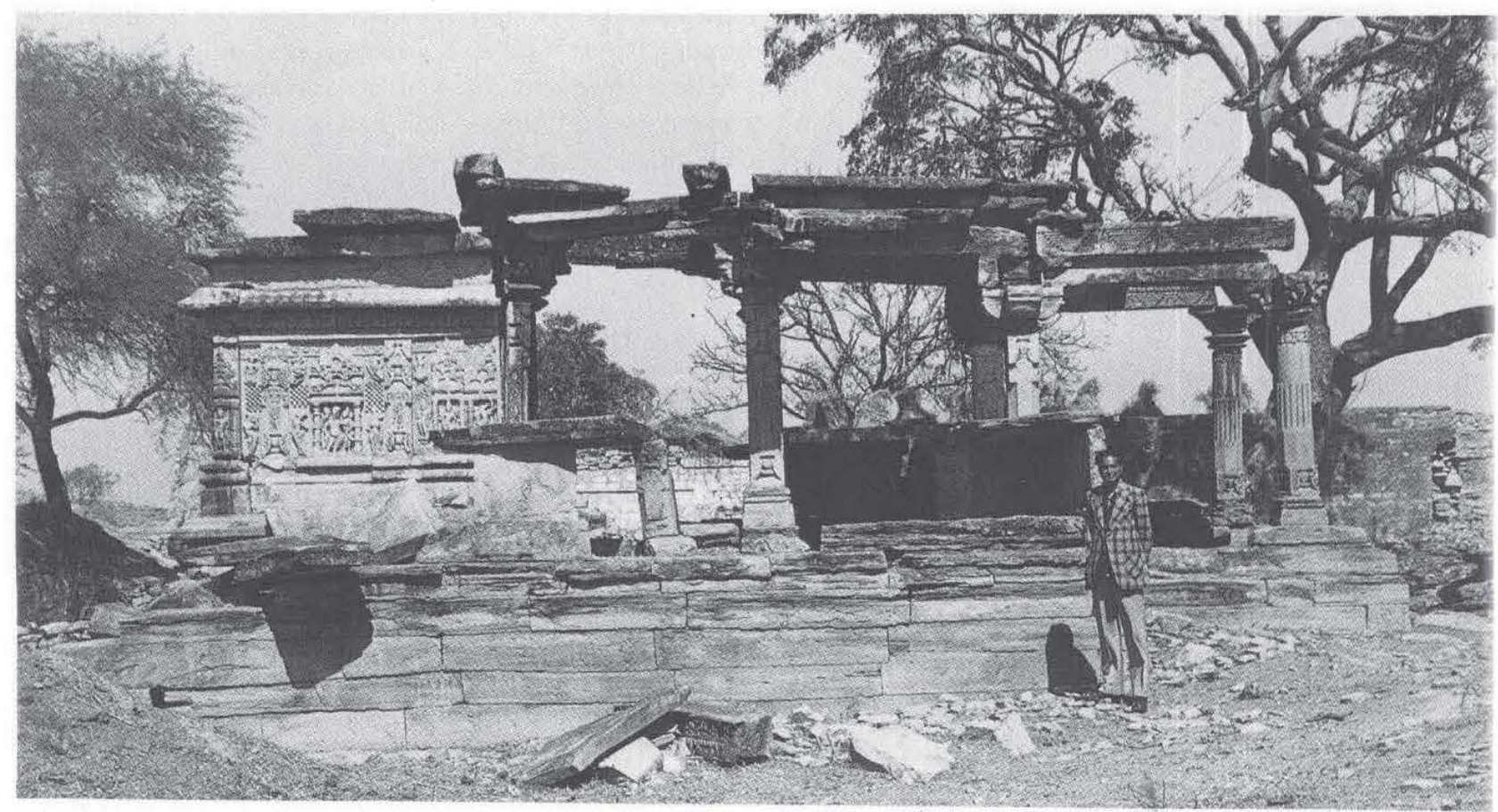

Fig. 18. Tilorī, Vișṇu temple, late 11th century.

of the door jambs to smooth panels and the absence of niches with figural sculpture. Perhaps the most startling feature is the way in which the components of the elevation (mandovara) have lost their architectural integrity and been reduced to a series of moulded courses.

An analogous reductionism is seen in the circular temple at Mitāolī (Fig. 20). This building, probably also from the time of Ratnapāla, has been heavily reconstructed, but its original appearance can be discerned. The outer walls are provided with offsets, each carrying a small niche and pediment. The niches flanking the rebuilt entrance contain figures of Śiva and Pārvatī; the others, where preserved, have only diamond-shaped lozenges. Below the niches is a continuous base consisting of a podium (vedibandha) and plinth (pittha). The mouldings are particularly sharp and compressed. Above the wall and its niches is a continuous entablature (varandikâ). Enough is preserved above the entablature to show that the temple was once ringed with small latina-shaped spires, something like the Ādinātha temple at Rānakpur. The spires at Mitāolī originally crowned small cells which faced inward to a cloistered court. In the centre of the court is a circular shrine to the god Siva, also rebuilt in its upper parts. The lower portion shows a moulded plinth and an open circular ambulatory supported by paired columns. The individual pillars have bases and double capitals, but lack carved flora ornament of any kind. The cells lining the courtyarc are empty, but they probably contained yogin images like the well-known temple at Bherāghāt (Sharma, 1978). Other buildings of this type are found at Khajurāho and Dudhahi (near Deogarh).

The last phase of architecture under the Kacchapaghātas is illustrated by the temples at Naresar (ancient Naleśvara). This site is best known for its 8th-century monuments, but additions were made in the 12th century as testified by several inscriptions. The earliest record of the period is dated VS 1202/A.D. 1145-46 and records a gift to a temple by the son of Śrī Haripāla. Not long after this are a group of mother-goddess images, now in the Archaeological Museum, Gwalior. These are inscribed with the name of the donor rāvala Śr Vāmadeva (Dvivedi, VS 2004, nos. 93 and 680-91) in one case the date is given as VS 1245/A.D 


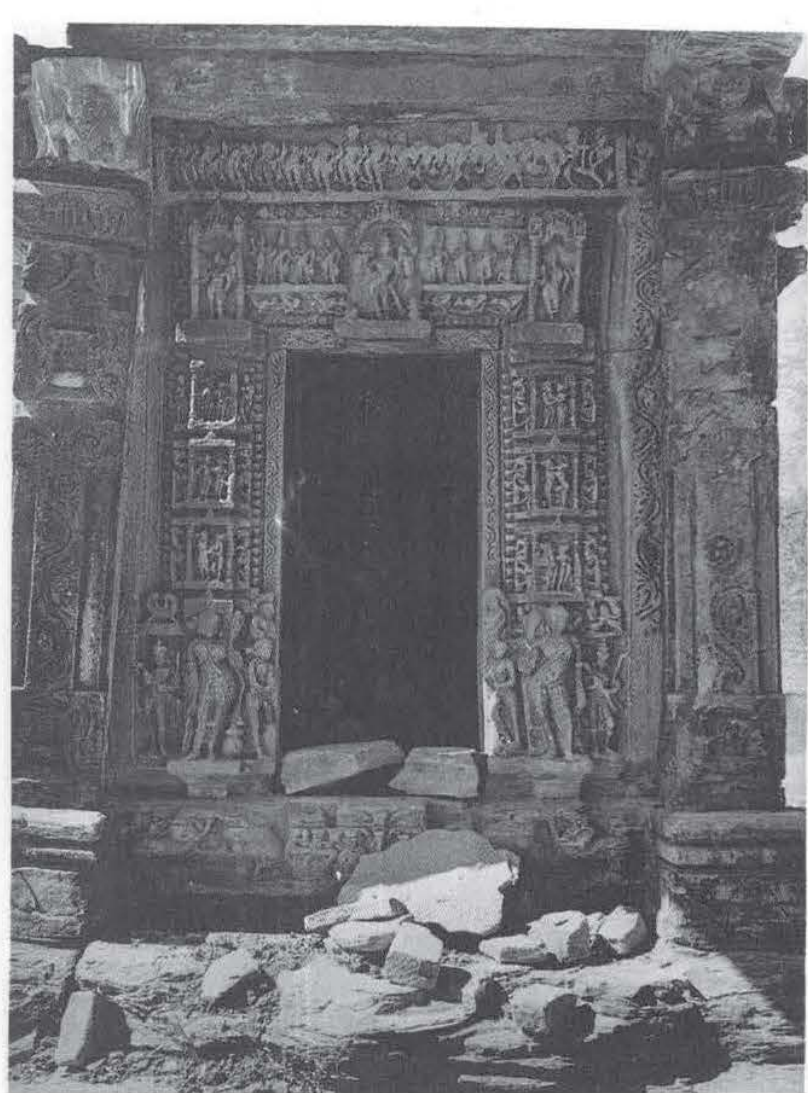

Fig. 19. Tilorī, Vișṇu temple, entrance door, late 11th century.

1188-89. Another image-inscription gives the date VS 1249 mārgaśīrșa śudi 2 ravivāra/ A.D. 8 November 1192 (Ramasharma, 1969). This records the establishment of an image, again by Vāmadeva, during the time of the Kacchapaghăta ruler Ajayapāla. Vāmadeva styles himself Doḍhakșetrapāla indicating that he was a minor noble, most probably from Gwalior where a later inscription describes one of the gates there as Dhoụhāpauri. Whatever Vāmadeva's position, his records allow us to assign most of the later buildings at Naresar to the late-12th century. In all probability the images of the goddesses were installed in the shrines at the site. The buildings, of which there is a considerable number, carry pyramidal and curvilinear superstructures. The pyramidal or phämsanā types consist of simple chamfered slabs of diminishing size (Fig. 21). The temple walls are without ornament and their bottom edge devoid of mouldings. Porches, when they do appear, are rudimentary in the extreme. Extending trends already apparent in the mid-11th century, the pillars are devoid of relief scuplture and show only faint vestiges of capitals and brackets. The latina-type temples are equally austere. The spires still have projecting faces but they lack carved ornament aside from slender fluted discs (karnaṇ̃daka). This development shows that by the late-12th century the spire was on the verge of becoming a simple, smooth turret. The large 12th-century temple at Naresar has a superstructure in the same style (Fig. 22). The lower portions, however, are more ambitious. The podium (vedïbandha) and plinth (pitha) are provided with recognizable mouldings and the wall with images. In marked contrast with the past, the images are not sheltered by pediments. The door has several jambs and corkscrew pilasters, suggesting that it was modelled on the Sãs Bahū temple at Gwalior. Indeed everything about these later shrines is derivative; they represent the lingering vestiges of a once great temple tradition which only a century before had produced some of the most spectacular buildings in the history of Indian architecture.

The sculpture of the late 12th century is marked by an equally dramatic breakdown of traditional practices and forms. Brittle modelling, awkward composition and misunderstood conventions combine to create an art which seems to be tottering on the verge of extinction. It was only in the 6th century, after the collapse of the Gupta dominion, that an analogous decline occurred. The goddesses from Naresar represent the case in point, but other examples are not wanting. Among the more intriguing pieces, and one that takes us into the second half of the 13th century, is a free-standing pillar at Tilori. The round shaft of the pillar is interrupted by a rectangular section with image panels. The failing ability of indigenous sculptors is neatly illustrated by this uninspired work (Fig. 23). A long inscription (Dvivedi, VS 2004, no. 619) of the ruler Kirtipāladeva is on the pillar but it has not been studied despite the fact that it is far from clear how the later Pratīhāras (to whom the Tilorī pillar apparently belongs) established themselves after the fall of the Kacchapaghantas. In these final years before the Khalji conquest, only the Yajvapālas of Narwar have received scholarly attention (Trivedi, 1959). 


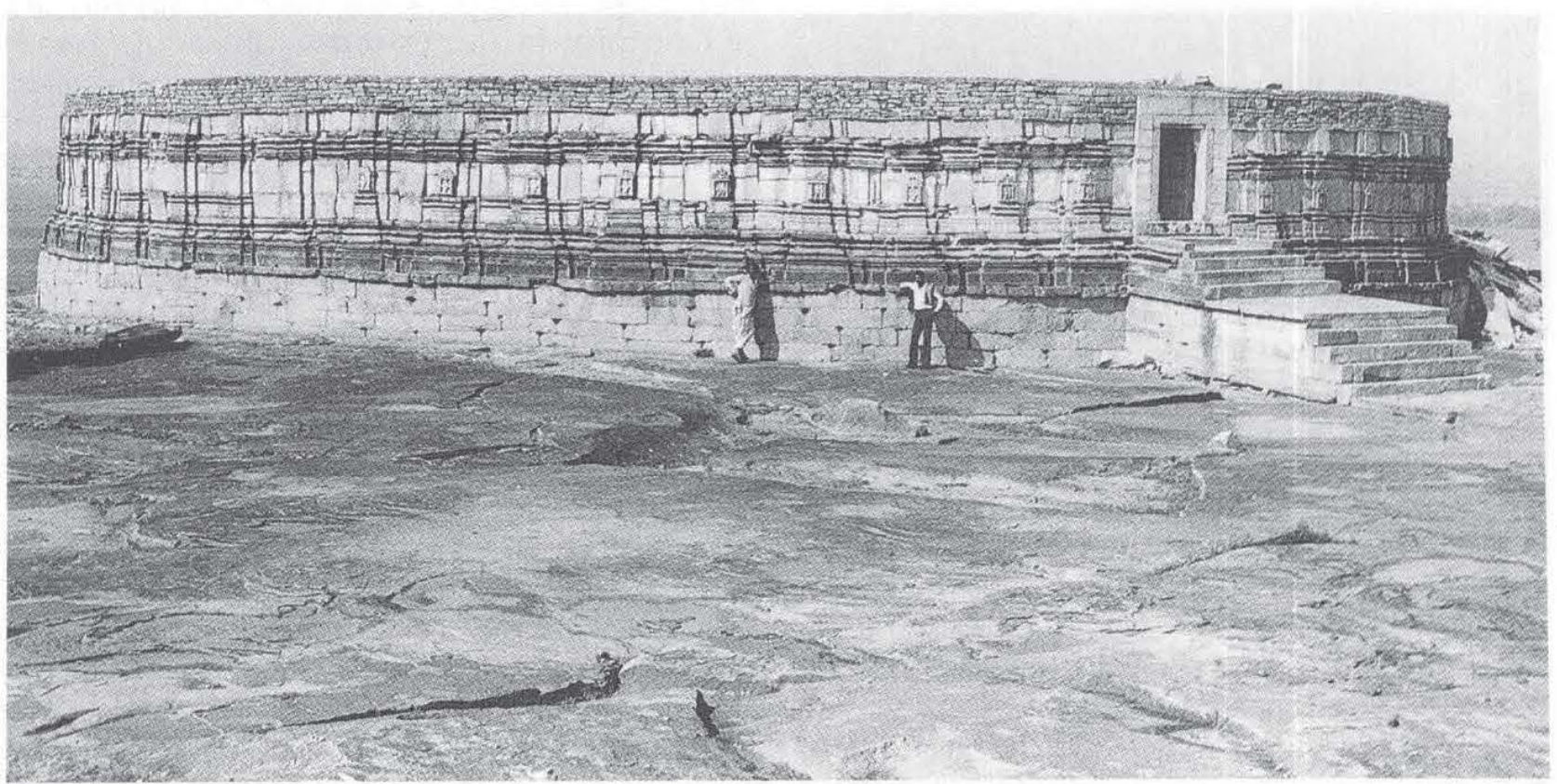

Fig. 20. Mitāolī, Yoginī temple, exterior, 12th century.

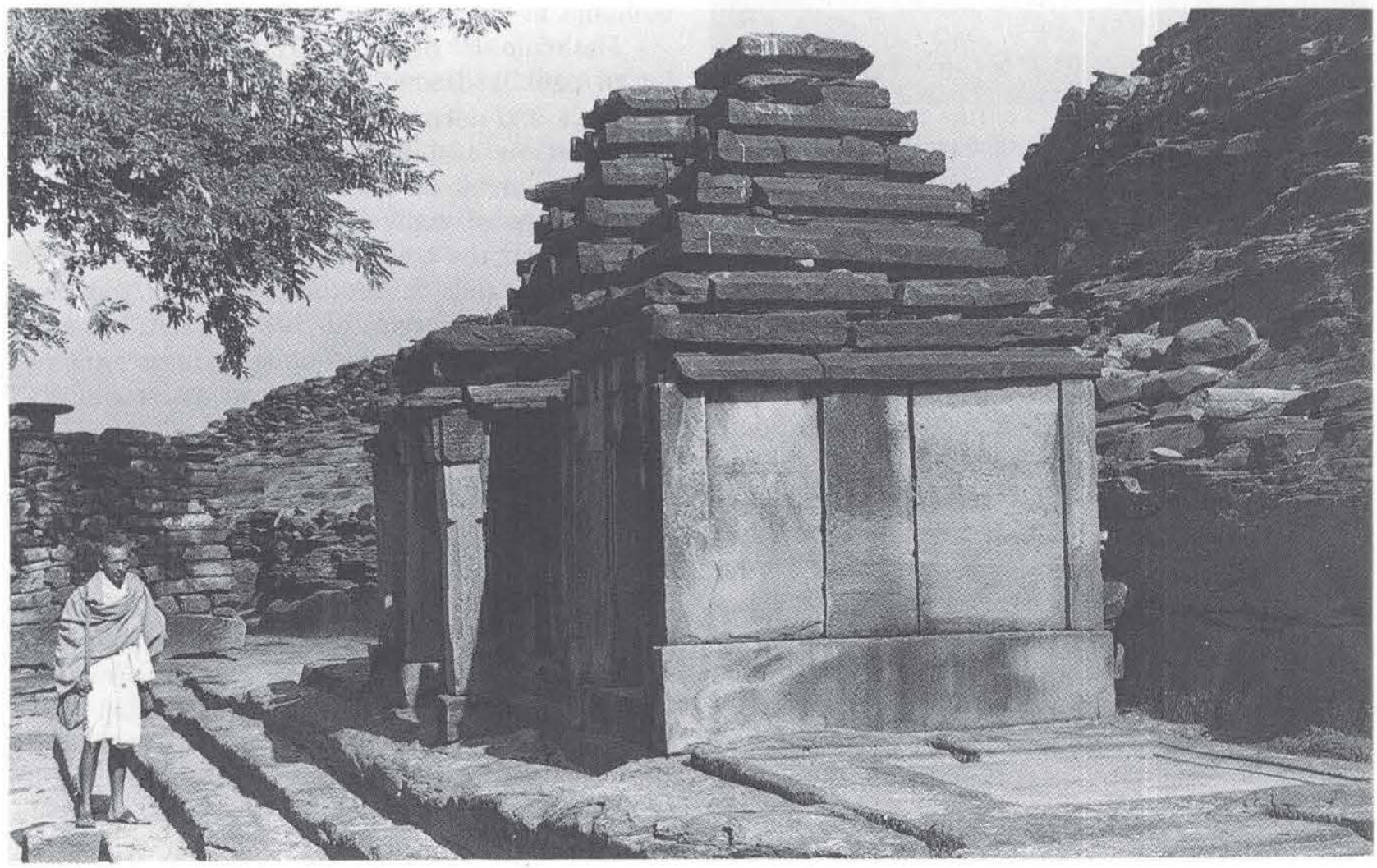




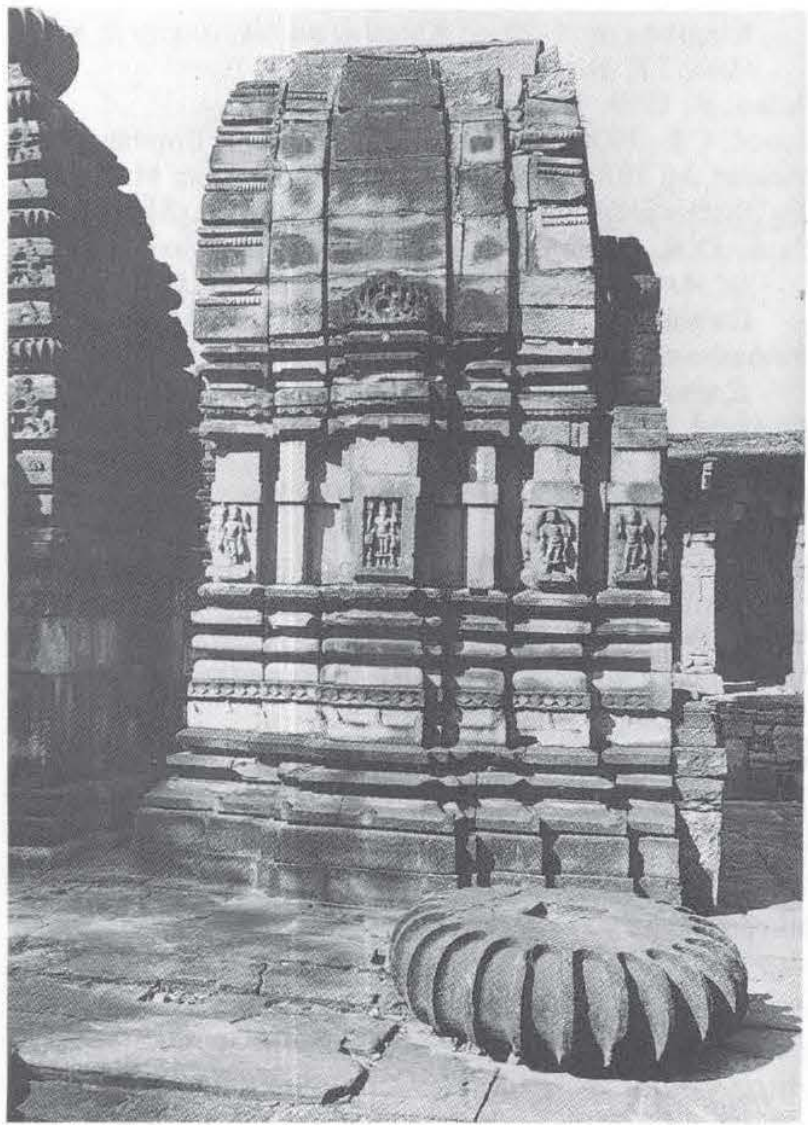

Fig. 22. Naresar, Śiva temple, late 12 th century.

\section{Conclusion}

I have ended with the Tilorĩ inscription to emphasize the fact that this essay is not a comprehensive history. I cannot claim to have covered all the important monuments of the Kacchapaghāta period and I have not tried to hide the deficiencies in the current state of our knowledge with regard to the documentation of buildings or the editing of inscriptions. There are virtually hundreds of buildings and dozens of inscriptions awaiting proper study and publication. The degree to which the subject has been ignored is indicated by Sihoniyã. This ancient capital has not merited an article, never mind a monograph, an astonishing situation if we think of the amount of work done on cities of analogous importance in medieval Europe. Alas

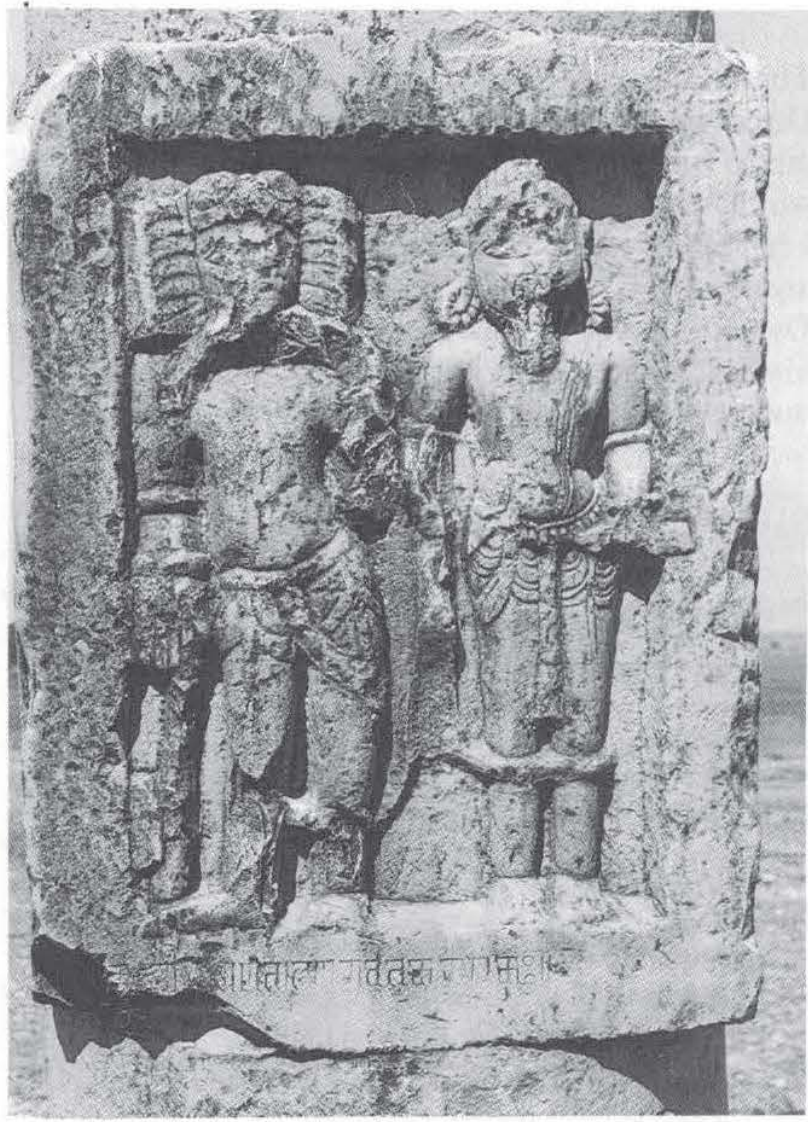

Fig. 23. Tilorī, relief figures on pillar of Kïrtipāla, 13th century.

Sihoniyā is only symptomatic of a larger problem of neglect. The time has past when we can consider our work done having blithely cited Patil's inventory of sites (Patil, 1952) or Dvivedi's list of inscriptions (Dvivedi, VS 2004). Invaluable as these sources are, they are based on reports written for the Archaeological Department of Gwalior State before World War II; many of the lesser-known sites and monuments have not been visited by historians or archaeologists for over half a century. A good case in point is Chait, a Jaina temple site southwest of Gwalior with several 12th-century temples. None have been published. What we urgently need is thorough documentation if we wish to go beyond the current restrictions within Indology and arrive at a substantive understanding of this important period in the history of India. 


\section{Acknowledgements}

This article was first suggested to me by Krishna Deva whose interest in my work has encouraged me to bring this and other projects to conclusion. I would also like to thank $\mathrm{H}$. V. Trivedi, with whom I have enjoyed lively correspondence regarding the archaeology and inscriptions of the region. H.N. Dvivedi and R.N. Misra not only shared their wide historical knowledge but opened their homes to me during my long stays in Gwalior.

\section{BIBLIOGRAPHIC REFERENCES}

Archaeological Department, Gwalior State, 1937-43, Annual Report, Samvat 1980, Year 1925-26 to Samvat 1997, Year 1940-41, Gwalior.

Archaeological Department, Gwalior State, 1949, Quinquennial Administration Report for Samivats 19982002 (Years 1942-46), Gwalior.

Babb, L.A. 1993. Monks and Miracles: Religious Symbols and Images of Origin among Osvāl Jains, Journal of Asian Studies, 52: 3-21.

Brown, Percy. 1944[?]. Indian Architecture, 2 vols., Bombay (with several later editions).

Davis, Richard H. 1993. Indian Art Objects as Loot. Journal of Asian Studies, 52: 22-48.

Deva, Krishna. 1959. Temples of Khajuraho, Ancient India, 15 , pp. 43-65.

Deva, Krishna. 1963-64. Kachcchapaghāta Temples. The Researcher, 3-4: 5-9.

Deva, Krishna. 1969. Temples of North India, New Delhi.

Deva, Krishna. 1987. Khajuraho, New Delhi.

Dirks, Nicholas B. 1987. The Hollow Crown: Ethnohistory of an Indian Kingdom, Cambridge; 2nd ed., 1993, Ann Arbor.

Dvivedi, Harihar Nivas. VS 2004. Gvāliyar rājya ke abhilekh, Banāras.

Dvivedi, Harihar Nivas. 1980. Gopakșetra ke kacchapaghāta, Gvāliyar darśan, Gwalior, pp. 186-216.

Handiqui, K.K. 1968. Yasastilaka and Indian Culture, or Somadeva's Yasastilaka and Aspects of Jainism and Indian Thought and Culture in the Tenth Century, 2nd edition, Sholapur.
Inden, R., 1978, Ritual, Authority and Cyclic Time in Hindu Kingship, pp. 1-27 in: Kingship and Authority in South Asia, J.F. Richards, ed., Madison.

Inden, R. 1990. Imagining India, Oxford.

Luard, C.E. 1908. Gwalior State Gazetteer, Bombay.

Meister, M. 1976. Construction and Conception: Mandapikā Shrines of Central India, East and West, 26: 409-418.

Patil, D.R. 1952. The Descriptive and Classified List of Archaeological Monuments in Madhya Bharat, Gwalior.

Ramasharma. 1969. Two Inscriptions of Ajayapaladeva. Epigraphia Indica, 38: 132-134.

Rowland, B. 1956. The Art and Architecture of India, 2nd edition, Baltimore.

Sharma, R.K. 1978. The Temple of Chaunsatha-Yogini at Bherāghàt, Delhi.

Sinha, V.K. 1980. Kacchapaghāta rājavamía kā navīna abhilekh, Gvāliyar darśan, Gwalior, pp. 217-219.

Sircar, D.C. 1966. Indian Epigraphical Glossary, Delhi.

Srinivasan, P.R. 1970. Five Gangola Tank-Bed Inscriptions. Epigraphia Indica, 38: 305-312.

Stein, Burton. 1983. Mahānavamĩ: Medieval and Modern Kingly Ritual in South India, pp. 67-90 in: Essays on Gupta Culture, Bardwell L. Smith, ed., Delhi.

Trivedī, H.V. 1953. The Bibliography of Madhya-Bhärata Archaeology, Gwalior.

Trivedi, H.V. 1959. The Yajvapālas of Narwar. Journal of the Madhya Pradesh Itithasa Parishad, 1: 22-32.

Trivedi, H.V. 1979-91. Inscriptions of the Paramāras, Chandellas and Kachchapapaghātas and two Minor Dynasties, Corpus Inscriptionum Indicarum, volume 7 (in 3 parts), New Delhi.

Trivedī, H.V. 1980. Kacchapaghāta nareśorn ke anuvamśaj, Gvăliyar darsan, Gwalior, pp. 214-216.

Trivedi, R.D. 1990. Temples of the Pratihara Period in Central India, New Delhi.

Watters, Thomas. 1904. On Yuan Chwang's Travels in India, 2 vols., London.

Willis, M. 1988. An Introduction to the Historical Geography of Gopakșetra, Das̄ārṇa and Jejākadeśa. Bulletin of the School of Oriental and African Ștudies, 51: 271-278.

Willis, M. 1993. Religious and Royal Patronage in North India, pp. 48-65, in: Gods, Guardians and Lovers, Vishakha Desai and D. Mason, eds., New York.

Willis M. 1996. Inscriptions of Gopaksetra: Materials for the History of Central India, London. 